\title{
Perceptions of Spirituality and Perceptions of God Image: A Qualitative Study
}

Christopher Elson Peck

Brigham Young University - Provo

Follow this and additional works at: https://scholarsarchive.byu.edu/etd

Part of the Counseling Psychology Commons, and the Special Education and Teaching Commons

\section{BYU ScholarsArchive Citation}

Peck, Christopher Elson, "Perceptions of Spirituality and Perceptions of God Image: A Qualitative Study" (2009). Theses and Dissertations. 1790.

https://scholarsarchive.byu.edu/etd/1790

This Dissertation is brought to you for free and open access by BYU ScholarsArchive. It has been accepted for inclusion in Theses and Dissertations by an authorized administrator of BYU ScholarsArchive. For more information, please contact scholarsarchive@byu.edu, ellen_amatangelo@byu.edu. 


\title{
PERCEPTIONS OF SPIRITUALITY AND PERCEPTIONS OF GOD:
}

\section{A QUALITATIVE STUDY}

\author{
by \\ Christopher E. Peck \\ A dissertation submitted to the faculty of \\ Brigham Young University \\ in partial fulfillment of the requirements for the degree of
}

Doctor of Philosophy

Department of Counseling Psychology and Special Education

Brigham Young University

August 2009 
Copyright (C 2009 Christopher E. Peck

All Rights Reserved 
BRIGHAM YOUNG UNIVERSITY

GRADUATE COMMITTEE APPROVAL

of a dissertation submitted by

Christopher E. Peck

This dissertation has been read by each member of the following graduate committee and by majority vote has been found to be satisfactory.

Date

Date

Date

Date

Date
Timothy B. Smith, Chair

Lane Fischer

Aaron P. Jackson

Daniel K. Judd

Roni Jo Draper 


\section{BRIGHAM YOUNG UNIVERSITY}

As chair of the candidate's graduate committee, I have read the dissertation of Christopher E. Peck in its final form and have found that (1) its format, citations, and bibliographical style are consistent and acceptable and fulfill university and department style requirements; (2) its illustrative materials including figures, tables, and charts are in place; and (3) the final manuscript is satisfactory to the graduate committee and is ready for submission to the university library.

Date

Accepted for the Department
Timothy B. Smith

Chair, Graduate Committee
Aaron P. Jackson

Department Chair

Accepted for the College

Barbara Culatta

Associate Dean, College of Education 


\begin{abstract}
PERCEPTIONS OF SPIRITUALITY AND PERCEPTIONS OF GOD: A QUALITATIVE STUDY
\end{abstract}

\author{
Christopher E. Peck \\ Department of Counseling Psychology and Special Education \\ Doctor of Philosophy
}

The vast majority of people living in the U.S. report that spirituality is an important part of their life. Ironically, the field of psychology has largely ignored the spiritual beliefs and experiences that so many people see as central to their well-being. Empirical study of spirituality, along with people's differing perceptions of their relationship to God, is a viable area of study for psychologists. This dissertation examines both spirituality and God image and the relationship between these two constructs using qualitative hermeneutic analysis. Findings showed a difficulty defining spirituality among other themes. Findings also showed that individuals' experiences with God led to more concrete descriptions of Deity, and participants often alluded to a gap between themselves and God that creates dissonance. It was generally easier for participants to describe God than spirituality, and religious concepts were integral to participants' descriptions of both spirituality and God. 
Implications for psychology and counseling include the limitations of current quantitative measurement of these constructs, the importance of addressing contextual worldviews, and issues relevant to counseling. 


\section{ACKNOWLEDGMENTS}

My expression of gratitude and heartfelt thanks to everyone who has generously influenced this project cannot be overemphasized. I acknowledge the many people who directly and indirectly influenced this work including the research participants. I especially thank my chair, Dr. Timothy Smith for his faith in me and his commitment to research in spirituality. I thank my committee for their time and efforts and I thank the rest of the CPSE faculty for giving me their best to assist in my professional and academic development.

I acknowledge and express thanks to my wife Heather for her sacrifice and support that enabled me to pursue this work. I thank my children Austin, Amanda, Zoe, and Sadie who sacrificed time they could have had with their dad while I worked on this dissertation. Also, I wish to thank friends and extended family for their support and encouragement along the way.

Lastly, I wish to thank my Father in heaven for his guidance and support in this undertaking. I recognize that my life has been richly blessed by His tender mercies and my witness of His powerful influence in the lives of His children. 
TABLE OF CONTENTS

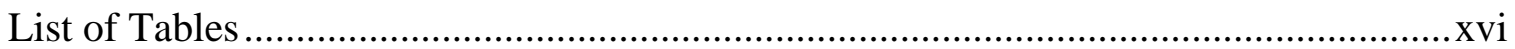

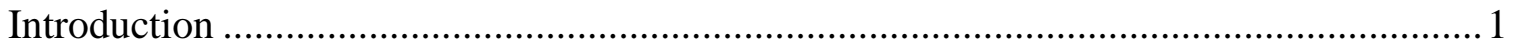

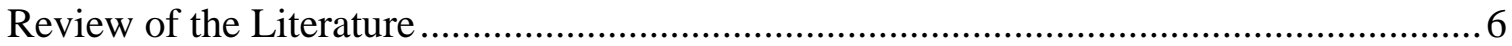

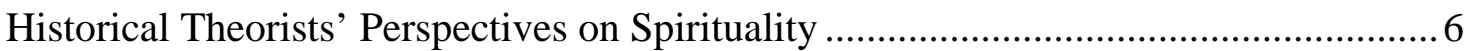

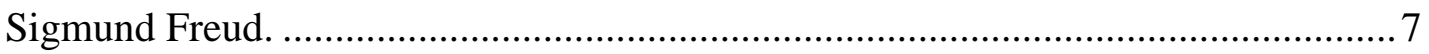

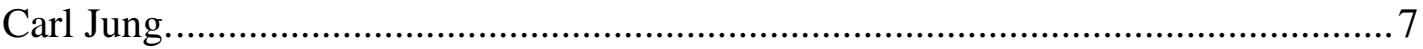

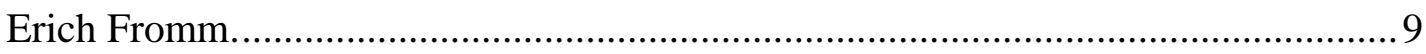

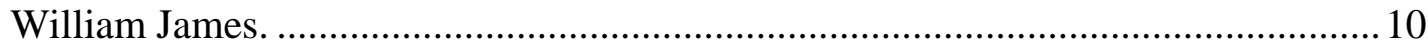

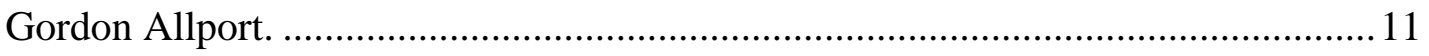

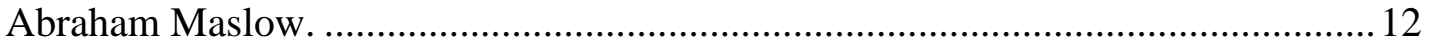

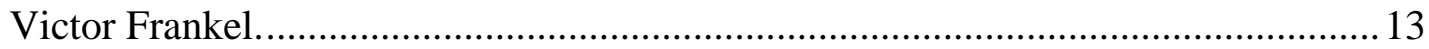

Contemporary Theorists’ Perspectives on Spirituality ............................................ 15

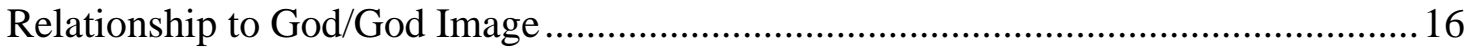

Quantitative Measures of Spirituality................................................................. 22

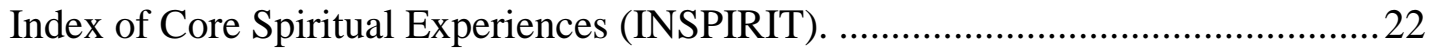

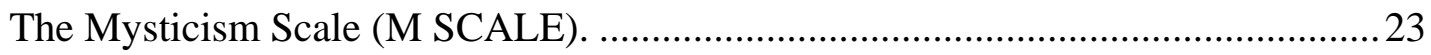

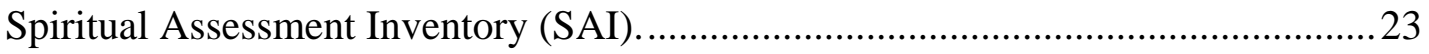

Spiritual Themes and Religious Response Test (STARR).....................................23

Spiritual Well-Being Questionnaire (SWBQ) ................................................. 24

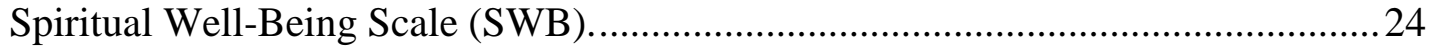

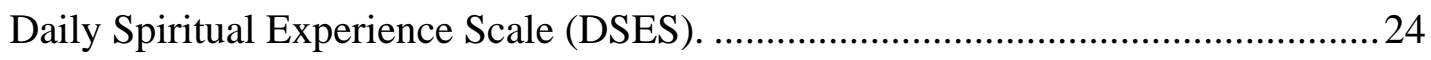

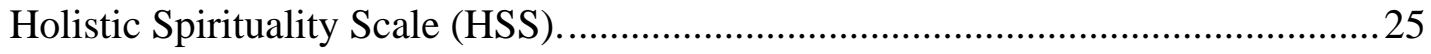




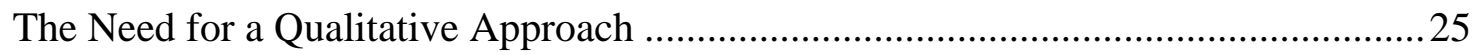

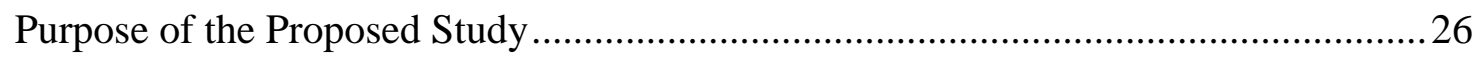

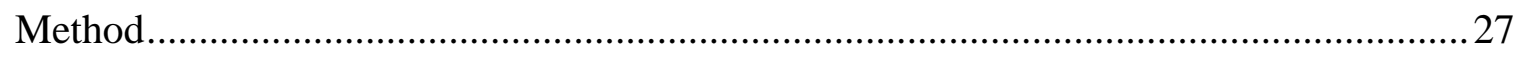

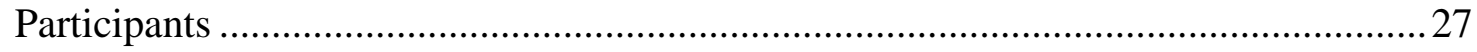

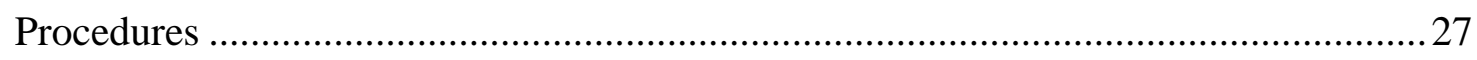

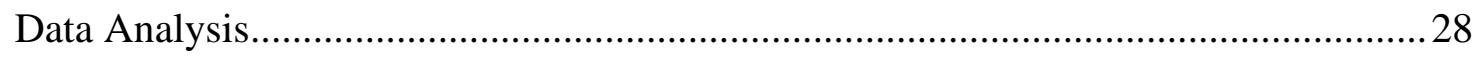

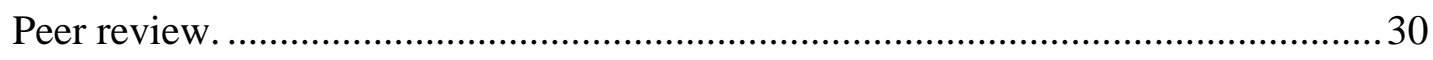

Reduction of analytic and interpretive bias. .................................................... 31

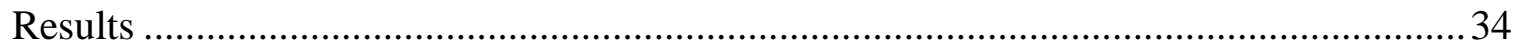

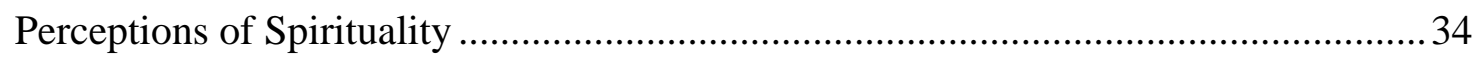

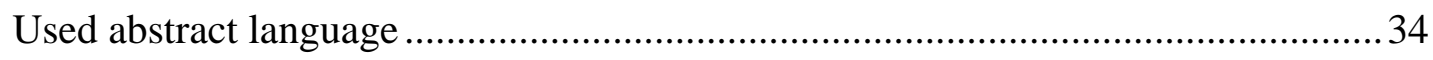

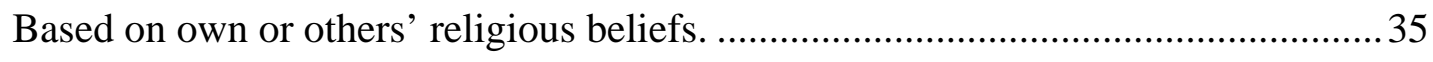

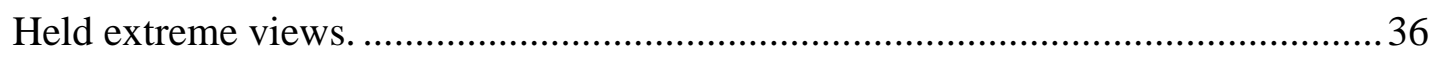

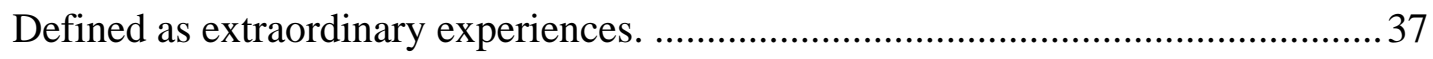

Relationships significant in descriptions of spirituality. .................................... 38

Viewed in terms of doing rather than being. .................................................... 38

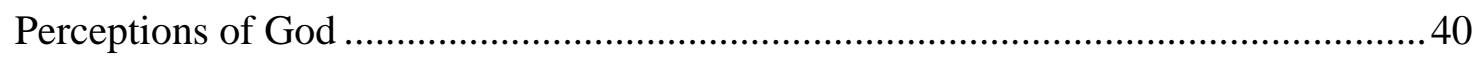

Experiences with God led to richer perceptions of Deity .................................... 40

Religiosity plays a role in describing God. ..................................................... 41

Gap between participant and God creates dissonance....................................... 42

God is more relevant in time of need. ........................................................... 45

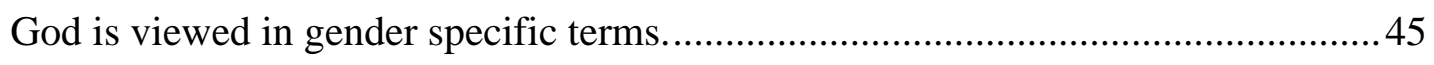

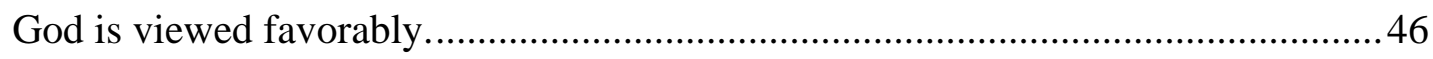


Correlation Between Perceptions of Spirituality and Perceptions of God ................... 46

Easier for participants to describe God than spirituality................................... 47

Differences when God is not viewed in anthropomorphic terms. ...........................4

Consistent perceptions within an integrated belief system..................................49

Abstract God_less personalized descriptions of spirituality. ...............................50

Religion as the culprit for any negative perceptions about God or spirituality......... 51

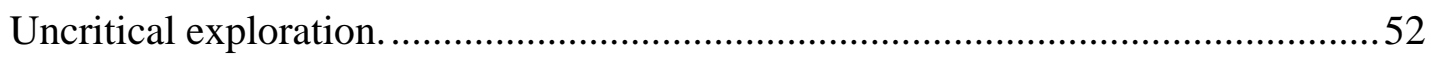

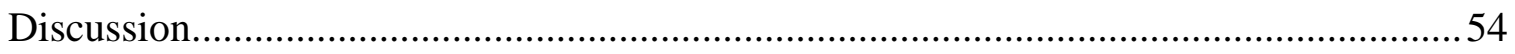

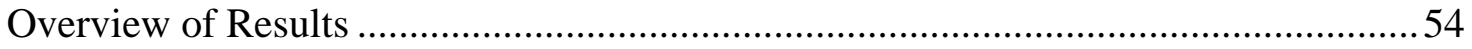

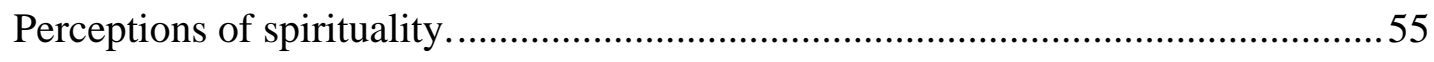

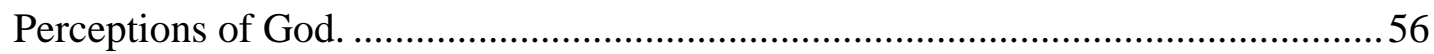

Association between perceptions of God and perceptions of spirituality. ...............57

Comparisons of Themes with Psychological Theorists' Ideas ...................................59

Comparisons with classical theorists........................................................... 59

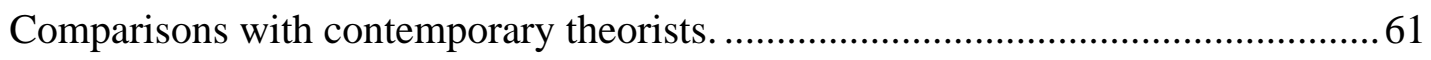

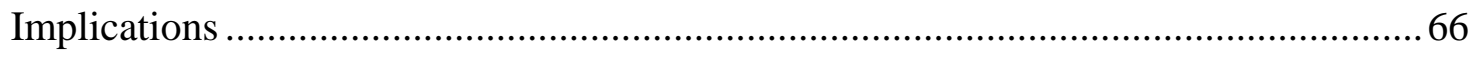

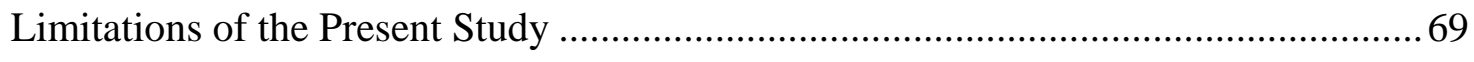

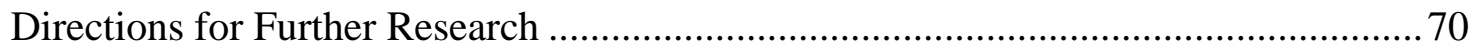

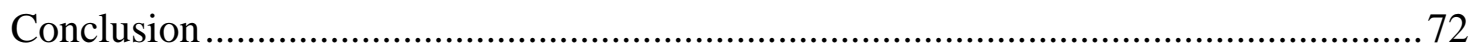

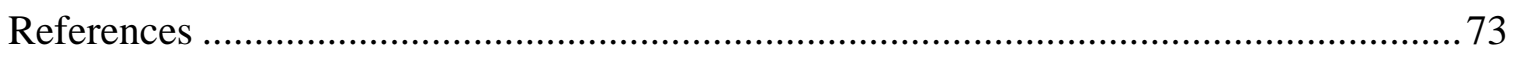

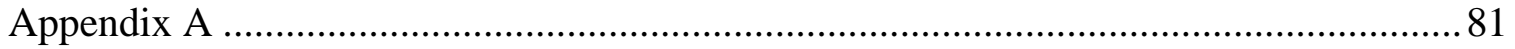




\section{List of Tables}

Table 1. Historical theorists’ perspectives of religious \& spiritual experience............ 14

Table 2. A sampling from the literature of contemporary theorists’ perspectives of

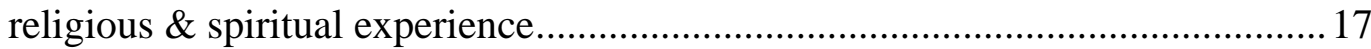




\section{Introduction}

Many people affirm the salience of religion and spirituality in their lives. Research shows that $87 \%$ of those living in the U.S. believe in God (Gallup, 2006), and $84 \%$ say spirituality is an important part of their daily life (CNN-Gallup, 2005). This widespread acknowledgement of the importance of spirituality appears to be related to the central role that spirituality plays in many people's worldviews, their very way of perceiving life. "We surround ourselves with spiritual references, creating a context in which the sacred is invoked to convey the significance of every major life event” (Spitka, Hood, Hunsberger, \& Gorsuch, 2003, p. 2). Spirituality and beliefs about God are not only foundational to interpreting major life events, but they appear to be the touchstone of values and meanings that individuals ascribe to their lives.

Given the ascribed salience of spirituality and relationship to Deity to nearly every aspect of life, particularly the inner life of the psyche, it stands to reason that spirituality and individuals’ perceptions of God are viable sources of inquiry for psychologists because of their psychological nature. Indeed, several scholars have argued that the study of spirituality can yield many insights for psychologists (e.g., Hill, 1999; Richards \& Bergin, 1997). Recent research also affirms that spirituality can benefit individuals both physically in the form of healing and psychologically in the form of well-being (Koeing, McCullough, \& Larsen, 2001; Miller \& Thoresen, 2003; Powell, Shahabi, \& Thoresen, 2003).

Despite the several theoretical and empirical efforts documenting the relevance of spirituality and perceptions about God to individuals’ well-being, the scientific 
study of these issues has historically been neglected within the social sciences (Bergin, 1980). However, scholarship in the area has been rapidly increasing since the early 1980s. Emmons and Paloutzian (2003) found in a literature search from 1988 to 2001 over 777 documentations for spirituality. A similar literature search conducted in 2005 revealed 2,494 citations referencing spirituality since 1990. The literature on the subject is rapidly growing.

Despite this accelerated growth in the psychological study of spirituality, it appears that there is no clear description for the construct of spirituality. In fact, the number of perspectives and the differences between those perspectives are remarkable (Zinnbauer et al., 1997; Zinnbauer \& Pargament, 2005). Given the salience of spirituality to psychology and the rapid proliferation of research on the topic, this fact seems more than a little ironic. It is doubtful that any other area of inquiry in psychology has such a large literature base without general agreement about the nature of the variable and its meaning.

In short, even though the literature is highly consistent in reporting positive associations between spirituality and mental health (e.g., Hill, 2005), the literature may be limited by the generic nature of the terminology used. The word spirituality conveys multiple meanings, such that research may be tapping into general rather than specific effects. Due to this lack of specificity, psychological perspectives of spirituality remain less complete than they ought to be.

In particular, although the psychology research literature frequently references individuals’ perceptions about God (often referred to as God image), psychological definitions of spirituality typically avoid mentioning Deity. That is, the study of 
spirituality and the study of perceptions of God are currently distinct areas of inquiry in the scientific study of religion (e.g., Hill \& Hood, 1999; Spilka, Hood, Hunsberger, \& Gorsuch, 2003). This implicit separation between definitions of spirituality and God image is partly due to the distinct historical origins of relevant scholarship, with the former originating in the philosophy of psychology (James, 1907/1972) and the latter originating from the psychoanalytic object relations literature (see Brokaw \& Edwards, 1994). Nevertheless, this historical separation of individuals' perceptions of spirituality from their perceptions of God no longer appears justified, particular because most individuals' spiritual beliefs are intertwined with their beliefs about Deity (Hill \& Hall, 2002; Hill \& Pargament, 2003).

Another likely reason for the implicit separation between psychological definitions of spirituality and psychological research of individuals’ perceptions of God is the general reluctance among psychologists to openly talk about influences that cannot be seen nor measured (Bergin, 1980). Assumptions about empirical science have often translated into agnostic or even atheistic affirmations (e.g., Ellis, 1980). Nevertheless, recent scholarship has challenged the association between rigorous scholarship and agnosticism/atheism and affirmed that psychological inquiry can be based upon Theistic principles that affirm the reality of God (Richards \& Bergin, 2005). Furthermore, because of the vital role spirituality and religion play in individuals' lives, consideration of theistic assessment and treatment strategies should be a critical component of any diversified treatment approach (Shafranske \& Sperry, 2005). 
A final reason for integrating descriptions of spirituality with individuals’ perceptions of God is related to how most people experience spirituality. Perceptions of spirituality typically exist within a relational context (Hall \& Brokaw, 1995; Hill \& Hall, 2002). Humans are social beings, and even highly abstracted concepts such as spirituality are often personalized in the process of meaning-making (Paloutzian \& Park, 2005; Spilka et.al, 2003). Therefore individuals’ perceptions of spirituality in general are likely to be intricately intertwined with their perceptions of Deity, the Being that personifies spirituality. It therefore seems reasonable for descriptions of spirituality to account for individuals’ perceptions that include beliefs about God.

One method for understanding the nature of spirituality is to ascertain what individuals intend to say when they use the term. Through a bottom-up approach to inquiry, descriptions come as researchers collect and organize the experiences and labels used by individuals. However, very few scholarly descriptions of spirituality have employed this method of inquiry. In fact, in the psychological literature the majority of attempts to describe spirituality have philosophical origins, based predominantly on the work of William James (Fontanta, 2003; Spilka et al., 2003; Zinnbauer \& Pargament, 2005). Thus, the preponderance of the literature regarding spirituality and psychology appears to be based upon top-down approaches, meaning a theorists’ description being constructed and placed upon participants.

Several scholars have argued for the benefit of bottom-up as opposed to topdown methods of inquiry (e.g., Zinnbauer, Pargament, \& Scott, 1999; Gorsuch; 1984). Particularly with respect to construct classification, it helps to be informed from people’s perceptions and perspectives and in getting at what they are thinking about. 
It would appear that this type of approach would be particularly beneficial when studying spirituality and individuals’ perceptions of Deity. Therefore, this manuscript will propose a qualitative research study of individuals’ perceptions of spirituality while also considering their perceptions of God. The purpose of the study will also be to relate how individuals describe spirituality and how their descriptions of spirituality relate with (or do not relate with) their perceptions of God. However, prior to specifying the particular aims and scope of the project, the general literature relevant to the topic will be reviewed. 
Review of the Literature

Having established the relevance of spirituality and God image to psychology and psychotherapy, this section will review historical perspectives on definitions of spirituality, followed by more contemporary perspectives. Next, research and theories regarding individuals’ perceptions of God will be reviewed. Finally, rationale and support for looking at individuals’ perceptions of spirituality and God image through a bottom-up-approach (using hermeneutic analysis) will be outlined.

\section{Historical Theorists’ Perspectives on Spirituality}

The topic of religion has been discussed and written about perhaps more than any other topic in all of humanity (Spilka et al., 2003). Religion and spirituality have been a primary component of human experience since the beginning of recorded history. The scientific study of religion came about during the late 1800s from differing fields including anthropology, philosophy, psychology, and sociology (Zinnbauer \& Pargament, 2005). These early theorists sought to explain religion through "objective” study of the human factors of religion, not accepting at face value the tenets promoted within the religions themselves.

Historically, the terms religion and spirituality were often used interchangeably under the broader construct of religion. Therefore, as early theoreticians are reviewed, it should be kept in mind that most of them referred primarily to religion and religious experiences. The concept of spirituality is a relatively newer term that in some cases was not differentiated within a particular paradigm. 
Sigmund Freud. Freud (1961) believed that religious belief was an illusion - a societal expression of neurosis. He argued that societies developed and maintained religious beliefs to cope with fears of the unknown, death, violence, etc. For Freud, religion acted as a defense mechanism for dealing with death as well as the childlike anxieties of people facing the unknown world. In the words of Freud (1961), "In this way all the terrors, the sufferings and hardships of life are destined to be obliterated” (p. 19).

Freud believed that people are an enemy to society and thus need regulation, with religion serving the purpose of suppressing sexual and aggressive instincts. In other words, religion was a means to establish compliance to societal norms with God being an oedipal projection of an all-powerful father-figure.

Tied to the idea of a father-like projection was Freud's analysis of religious experience being akin to a mystical sense of oneness and an infantile feeling. Freud suggested that this mystic or "oceanic feeling" was another way for people to describe a longing for the Father; a connection to Deity’s power.

When it came to religious doctrine and practice, Freud (1907) injected the idea that religious behavior was as an obsessive-compulsive form of neurosis:

I am certainly not the first to be struck by the resemblance between what are called obsessive acts in neurotics and those religious observances by means of which the faithful give expression to their piety. The name 'ceremonial' which has been given to certain of these obsessive acts, is evidence of this. (p. 25) Carl Jung. Compared to Freud, Jung (1971) had a much more favorable outlook on religion. Though both came from a psychodynamic tradition, Jung viewed 
spiritual desire as more fundamental than the instinctual motivating forces of sexuality and aggression that were emphasized by Freud. Rather than incestuous motivation, Jung considered human's innate interest in spiritual issues to be a fundamental desire for re-birth. He saw that religious motivations were related to a desire to transform the psyche to a higher level of consciousness.

Jung believed that there is a healing power associated with symbolic expression of religious phenomena. He argued that one does not come to "know" through rational means or blind faith, but rather through experience. This innerexperience and understanding of religion led him to have less concern for historical truth as opposed to psychological truth regarding the meaning of religious experiences.

Although Jung believed human growth and development came about through the process of individuation, he was more specific in arguing that religious experience was transcendence over one's isolated individuality. This idea of transcended selfhood was indicative of union with God. For Jung, the value of religion was in its ability to transform the human personality. In short, he held that religion and individuation were the means to the same end.

Jung speculated that when people became ill it was because they had lost connectedness with the naturally religious inner psyche. Thus, he was weary of the organized religious masses engulfing the individual into their collective identity and thwarting the powerful "individual-connectedness." He echoed the same sentiment regarding dogmatism and logical discourse, arguing that this is where one loses the sanctity of the holy. Jung (1938) maintained that 
Such problems are never solved by legislation or tricks. They are only solved by a general change of attitude. And the change does not begin with propaganda and mass meetings, or with violence. It begins with a change in individuals. It will continue as a transformation of their personal likes and dislikes of their outlook on life and of their values, and only the accumulation of such individual changes will produce a collective solution. (p. 95)

Erich Fromm. Fromm emphasized that the history of religious phenomena was not as important as psychological criteria for defining religious experience. Simply put, religion was not about origin (creed) but value (behavior). Moreover, "religion” Fromm (1951) stated is, "any system of thought and action shared by a group which gives the individual a frame of orientation and an object of devotion” (p. 21). He broke these thoughts and actions relevant to religion into two types, authoritarian and humanistic.

Fromm believed that authoritarian religion signified submission to authority and deferment of fundamental man to God. In this view man is seen as insignificant and powerless juxtaposing God's omniscience and all-power. It is through surrendering one's all to God that man can finally feel strength. Fromm saw this submission of power as a pathway of escape from aloneness and isolation.

On the other hand, humanistic religion meant greater self-realization and oneness with self. Fromm (1951) held that “Man’s aim in humanistic religion is to achieve the greatest strength, not the greatest powerlessness; virtue is self-realization, not obedience” (p. 37). Faith was more a certainty grounded in experience and feeling. Fromm (1951) stated that this type of religion differed with authoritarian 
religion in that joy was the overarching mood rather than sorrow and guilt. Thus, he viewed God as a “symbol of man’s own powers which he tries to realize in his own life” (p. 37).

Fromm stated that when man projects his values and powers onto God then he in turn becomes alienated from himself. Moreover, the only way back to the self is through God. Fromm believed that the idea of being a "sinner" is really because of depravation of all that is good and an appeal to God's mercy and grace to get back what one already had.

William James. James held a more positive view of religion than Freud, and he had conflicting views regarding God and religion. In his early career, he claimed that God was the one "who challenges human beings to moral action and stimulates their latent capacities for the strenuous life and their moral energies” (Forsyth, 2003, p. 115). Later he proposed that God was one who, “comforts the 'sick soul,' heals the divided self, and brings about conversion” (p. 115). In other words, instead of God as "stimulator," it is God as provider of saving experiences. This was the impetus for his essays that later became the renowned book Varieties of Religious Experience. James (1902/1963) believed that religious experience is the true foundation of religious life. He separated religion into two aspects, one being "institutional” and the other being “individual.” He defined such individual experience as, “The feelings, acts and experiences of individual men in their solitude, so far as they apprehend themselves to stand in relation to whatever they may consider the divine” (p. 31).

At the most fundamental level religion was a personal experience and an original source of religious experience. James (1902/1963) felt that people were quick 
to label religion in the institutional or "ecclesiastical" sense and while he accepted this he was quick to put forth that "There must be something solemn, serious, and tender about any attitude which we denominate religious...It is precisely as being solemn experiences that I wish to interest you in religious experiences” (p. 38).

James contended that there are two types of this religious experience, healthyminded and sick. The former involved the pluralist who accepts imperfection and difference in reality and works toward making it better while the latter, the monist, looks passively for comfort and redemption. James figured that the value of religion came from its fruits and pragmatic results and he asserted that "The completest religions would therefore seem to be those in which the pessimistic elements are best developed” (p. 165). For James, evil may indeed hold some of reality's most profound truths.

Gordon Allport. Allport (1952) noted changes that were going on in Western societies with the acknowledgement of Eastern philosophies, "new age” movements, and other culture-influenced thinking. He knew that many people purported to believe in God and considered themselves religious; he also felt that many people had doubts about their particular religion and thus were turning elsewhere. It was in this era that the dichotomy became notable between religiousness and spirituality. This dichotomy implied that one can go beyond religion to gain spiritual fulfillment. Allport avoided this distinction and instead promoted the idea of "sentiment" which includes both the subjective (doctrines, values, etc.) and objective (the way the person incorporates the values and doctrines). He felt that these traits were unique to each individual and thus 
contradictory to Freudian instinct theory, or common mechanisms. Allport (1952) viewed mature religious sentiment as

a disposition, built up through experience, to respond favorably, and in certain habitual ways, to conceptual objects and principles that the individual regards as of ultimate importance in his own life, and as having to do with what he regards as permanent or central in the nature of things. (p. 56)

Allport put forth that mature religious sentiment fulfilled the human need for ultimate meaning and purpose and that it led to the way of the "examined life.” He further alleged that this type of sentiment was the formalization of conscience. Hence, religion served the purpose of enlarging and completing one's own personality by finding one's place within the supreme context.

Abraham Maslow. Maslow (1970) sought to distinguish organized religion and personal experience by stating that the latter is the primary element in religion. He further argued in his definition of religion the idea of "essential righteousness” (p. 47). In other words, peak or mystical experiences occurring outside of formalized religion meant that a "coalition” of many people and faiths could be enabled. He viewed belief in a supernatural being to be of secondary importance. He also believed that religious experience could be understood through scientific means.

Maslow did not care to offer a distinction between religious and natural values. Rather, he incorporated the human need for self-actualization to explain the need for religious experiences. He argued that the way we define religious experience implies that it can only occur in a religious context as opposed to a naturalistic one. He maintained that doctrine and rituals were attempts to make a prophet's original "peak 
experience" available to the masses. He also believed that religion was a means of putting "supernatural sanctions" to values that could already be stated in naturalistic terms. Hence, he concluded that religious experience was a combination of innate human values and natural experience.

Victor Frankel. Frankel (1975) suggested that spirituality was the most unique dimension about a person. He looked past instincts and learned behaviors as the motivating force and instead concluded that spirituality was to discover the meaning in one’s existence or a search for “ultimate meaning.” Furthermore, Frankel held that "spiritual phenomena may be unconscious or conscious; the spiritual basis of human existence, however, is ultimately unconscious” (p. 31). In other words, religion is the conscious expression of something innately unconscious along with our sense of morality.

Frankel also asserted that conscience is a referent to transcendence and that without the context of transcendence conscious is devoid of meaning. So, for Frankel the experience of "self-transcendence," or meaning within the context of something that transcends the self (God, cause, idea, etc.) is what makes our experience consciously religious. Responsibility comes forth when one exercises commitment to conscience.

In summary, there have been many theoretical approaches to spirituality. In their attempts to describe the topic and its corresponding experience we see a large diversity of thought and definitions provided across these early theorists. 
Table 1

Historical Theorists’ Perspectives of Religious \& Spiritual Experience

\begin{tabular}{|c|c|c|}
\hline Theorist & Perspective of Spirituality & Underlying Assumptions \\
\hline Sigmund Freud & $\begin{array}{l}\text { Mystical sense of oneness } \\
\text { with the universe is a } \\
\text { projected yearning for } \\
\text { oneness with parents }\end{array}$ & Intrapsychic \\
\hline Carl Jung & $\begin{array}{l}\text { Wholeness; realization of self; } \\
\text { connection to God }\end{array}$ & Multidimensional \\
\hline William James & $\begin{array}{l}\text { The healing of the divided } \\
\text { self; relationship to the divine }\end{array}$ & $\begin{array}{l}\text { Relational, experiential, } \\
\text { contextual }\end{array}$ \\
\hline Erich Fromm & $\begin{array}{l}\text { Realization of human power } \\
\text { and transcendence of ego }\end{array}$ & Pragmatic \\
\hline Gordon Allport & Intrinsic religious sentiment & Humanistic \\
\hline Abraham Maslow & Peak experiences & Transcendental \\
\hline Victor Frankl & $\begin{array}{l}\text { Responsibleness to God; } \\
\text { transcending self }\end{array}$ & Existential \\
\hline
\end{tabular}

Given the remarkable diversity of thought about spirituality among historical figures in psychology, it should be no surprise to discover diversity and perplexity in modern conceptualizations of spirituality. 


\section{Contemporary Theorists' Perspectives on Spirituality}

Since the 1980s the amount of scientific and scholarly work in the area of religion and spirituality has flourished. Likewise, the number of attempts to describe spirituality has thrived to the point that “it is as if a 'critical mass' of vague descriptions has been reached” (Spilka et al., 2003. p. 9). The lack of consensus in describing spirituality threatens to impede progress in this crucial area of inquiry (Emmons \& Paloutzian, 2003). This problem is exacerbated with the recent negative views attached to the term religion. This has caused a recent movement to completely distinguish spirituality and religion, much to the disparagement of many researchers (e.g., Zinnbauer \& Pargament, 2005; Spilka et al., 2003).

The picture of this struggle to parse out definitions of spirituality and religion is best painted by Bauman (1998) when he observed that,

'Religion' [spirituality] belongs to the family of curious, and often embarrassing concepts, which one perfectly understands until one wants to define them...More often then not, ‘defining religion’ amounts to replacing one ineffable with another-to the substitution of the incomprehensible for the unknown. (p. 55)

Due to the several common factors embedded, religious definition will be subsumed under the umbrella of spirituality for the purpose of the present study, although many argue a distinctness with spirituality being internal and religious being external (see Shafranske \& Sperry, 2005).

Various studies have attempted to compile contemporary perspectives of spirituality (Zinnbauer \& Pargament. 2005; Gorsuch 2002; Hill et al., 2000; \& 
Zinnbauer, Pargament, \& Scott; 1999). The descriptions found within these studies and others are outlined in Table 2.

The list of spiritual meaning is by no means exhaustive if you consider other cultures, religions, and beliefs (e.g., Buddhist, mysticism, paranormal, etc.). Truly, a close inspection of the literature will lead one to conclude, as did Spilka (2003), that spirituality is "a word that embraces obscurity with a passion” (p. 1). It is also evident that spiritual descriptors are multidimensional and that these descriptions may only be sufficient to their creators and not meaningful in other contexts. Similar conclusions may apply to definitions of spirituality that have been derived from quantitative empirical research.

\section{Relationship to God/God Image}

It is important to acknowledge that people's perceptions of spirituality exist within a relational context (Hall \& Brokaw, 1995; Hill \& Hall, 2002). Humans are social beings, and even highly abstracted concepts such as spirituality are often personalized in the process of meaning-making (Paloutzian \& Park, 2005; Spilka, et.al, 2003). Hence, perceptions of spirituality in general should be intricately intertwined with perceptions of Deity, the Being that personifies spirituality. Within the social science literature, individuals' perceptions of God are frequently referred to as God image (e.g., Eurelings-Bontekoe, Verhagen, \& Zock, 2002). The current study will address the association between God image and people’s general perceptions of spirituality. 
Table 2

A Sampling from the Literature of Contemporary Theorists' Perspectives of Religious \& Spiritual Experience

\begin{tabular}{|c|c|c|}
\hline Category & Author/Year & Description of Spirituality \\
\hline $\begin{array}{l}\text { Connectedness } \\
\text { /Relational }\end{array}$ & $\begin{array}{l}\text { Armstrong (1995) } \\
\text { Benner (1989) } \\
\text { Dollahite (1998) }\end{array}$ & $\begin{array}{l}\text { The presence of a relationship with a Higher Power } \\
\text { that affects the way in which one operates in the world. } \\
\text { The human response to God's gracious call to a } \\
\text { relationship with himself and our response to a deep } \\
\text { and mysterious human yearning for self-transcendence } \\
\text { and surrender, a yearning to find our place (p. 20). } \\
\text { A covenant faith community with teaching and } \\
\text { narratives that enhance the search for the sacred and } \\
\text { encourage morality (p. 5). }\end{array}$ \\
\hline $\begin{array}{l}\text { Humanistic/ } \\
\text { Existential }\end{array}$ & $\begin{array}{l}\text { Doyle (1992) } \\
\text { Hart (1994) }{ }^{\mathrm{a}}\end{array}$ & $\begin{array}{l}\text { The search for existential meaning (p. 302). } \\
\text { The way one lives out one's faith in daily life, the way } \\
\text { a person relates to the ultimate conditions of existence } \\
\text { (p. 23). }\end{array}$ \\
\hline Introspective & $\begin{array}{l}\text { Vaughan (1991) } \\
\text { Hill, et al. (2000) }\end{array}$ & $\begin{array}{l}\text { A subjective experience with the sacred (p. 105). } \\
\text { The feelings thoughts, experiences, and behaviors that } \\
\text { arise from a search for the sacred. The term "search" } \\
\text { refers to attempts to identify, articulate, maintain, or } \\
\text { transform. The term "sacred refers to a divine being, } \\
\text { divine object, Ultimate Reality, or Ultimate Truth as } \\
\text { perceived by the individual (p. 66). } \\
\text { The inner experience of the individual when he senses } \\
\text { a Beyond, especially as evidenced by the effect of this } \\
\text { experience on his behavior when he actively attempts } \\
\text { to harmonize his life with the beyond (p. 22). } \\
\text { That which is involved in contacting the divine within } \\
\text { the Self or self. (p. 274). }\end{array}$ \\
\hline
\end{tabular}




\begin{tabular}{|l|l|l|}
\hline Category & Author/Year & Description of Spirituality \\
\hline $\begin{array}{l}\text { Multi- } \\
\text { dimensional }\end{array}$ & $\begin{array}{l}\text { Richards \& Bergin } \\
\text { (1997) }\end{array}$ & $\begin{array}{l}\text { Those experiences, beliefs, and phenomena that pertain } \\
\text { to the transcendent and existential aspects of life [i.e., } \\
\text { God or a Higher Power, the purpose and meaning of } \\
\text { life, suffering, good and evil, death, etc.] (p.13). }\end{array}$ \\
Tart (1975) & $\begin{array}{l}\text { The vast realm of human potential dealing with } \\
\text { ultimate purposes, with higher entities, with God, with } \\
\text { love, with compassion, with purpose (p. 4). }\end{array}$ \\
Elkins, et.al.(1988) & $\begin{array}{l}\text { A way of being and experiencing that comes about } \\
\text { through awareness of a transcendent dimension and } \\
\text { that is characterized by certain identifiable values in } \\
\text { regard to self, life, and whatever one considers to be } \\
\text { the ultimate (p. 10). }\end{array}$ \\
\hline Transcendent & $\begin{array}{l}\text { Shafranske \& } \\
\text { Gorsuch (1984) }\end{array}$ & $\begin{array}{l}\text { a transcendent dimension within human } \\
\text { experience... attempts to place the self within a broader } \\
\text { ontological context (p. 231). }\end{array}$ \\
\hline Note: ${ }^{a}$ Contained in Handbook of the Psychology of Religion and Spirituality
\end{tabular}

The concept of God image has its roots in the psychoanalytic tradition of object relations theory. It originated from Freud's belief that God was a father-like projection with the ultimate aim of tension reduction and pleasure seeking (Freud, 1961). Object relations theorists after Freud, such as Fairbairn and Klein, replaced his emphasis on sexual motivations with an emphasis on social/emotional motivations, particularly the need to establish and maintain close connections with others (Mitchell, 2000). John Bowlby’s (1969, 1973) attachment theory stems from this object relations framework, and it has clear implications for how people’s perceptions of spirituality might be associated with individuals’ God image. The basic premise of attachment theory is that when an attachment figure (i.e., God) is perceived as being available and 
helpful, then the individual will be more likely to function confidently in the environment (e.g., have faith in contexts perceived to be spiritual). Oppositely, when an attachment figure is perceived as unavailable, disinterested, or capricious, then the individual will mistrust and doubt (Kirkpatrick, 2005, 1992; Rowatt \& Kirkpatrick, 2002). If this theorized association between God image and perceptions of spirituality is accurate, then it would not be surprising to find a parallel in spiritual functioning to Ainsworth and colleagues' (1978) attachment styles of secure, avoidant, and anxious/ambivalent.

Numerous studies have attempted to demonstrate the salience of individuals' attachment to God (see Rowatt \& Kirkpatrick, 2002). For example, the Attachment to God Scale was developed by Kirkpatrick and Shaver (1990) based on the attachment styles described by Ainsworth:

Secure: God is generally warm and responsive to me; He always seems to know when to be supportive and protective of me, and when to let me make my own mistakes. My relationship with God is always comfortable, and I am very happy and satisfied with it.

Avoidant: God is generally impersonal, distant, and often seems to have little or no interest in my personal affairs and problems. I frequently have the feeling that He doesn't care very much about me, or that he might not like me. Anxious-Ambivalent: God seems to be inconsistent in His reactions to me; He sometimes seems very warm and responsive to my needs; but sometimes not. I'm sure that he loves me and cares for me, but sometimes He seems to show it in ways I don’t really understand (Rowatt \& Kirkpatrick, 2002, p. 639). 
Research using this paradigm has generally found positive associations of secure attachment styles with a host of positive mental health variables, whereas avoidant and anxious-ambivalent attachments styles are typically positively associated with pathology (e.g., Kirkpatrick, 1990, 1992, 1995, 2005; Kirkpatrick \& Shaver, 1990, 1992; Rowatt \& Kirkpatrick, 2002).

Several other researchers have also set out to identify the relationship between God image and mental health. (See the Appendix for a listing and description of several quantitative measures of God image). More than 30 years ago, Benson and Spilka (1973) found that self-esteem was related with loving God images, whereas negative self-esteem was associated with a rejecting, controlling, and an impersonal God. O’Brien (1982) qualitatively linked God image concepts of providing comfort, nurturance, and the source of strength to aid in successful coping and in dealing with alienation. Hall and Brokaw (1995) built upon a string of studies supporting the notion that spiritual maturity and thus psychological well-being is related to a positive God image and mature object relations development. Many other studies have demonstrated that a negative God image can promote pathological personality development and psychological distress (see Eurelings-Bontekoe, Janneke HekmanVan Stegg, \& Verschuur, 2005; Schapp-Johnker, et al., 2002). In an extensive review of the relevant research literature, Spilka and colleagues (2003) concluded that God image served an essential psychological function in providing explanations for unexplainable events in their lives, "the many concepts of God that are held can be called upon as needed to explain occurrences that seem to defy naturalistic interpretation” (p. 506). Thus, individuals’ God image is apparently related to how 
they interpret ambiguous events and maintain a sense of consistent meaning in their lives.

Recent research has also begun to recognize the complexity of the association of God image to individuals’ well-being and worldviews. Kunkel et al. (1999) provide a detailed comprehensive conceptual map of God image and reasoned that "God images are multidimensional and varied” (p. 200). Furthermore, they went on to assert that much of the previous research into perceptions of God image is based on reductionistic and positivistic traditions within the field of psychology and that “underlying latent structure of God images may not be discoverable by use of correlational approaches that have predominated the field” (p. 194). Qualitative methods of inquiry are a plausible way to describe how God image is viewed with other important variables such as spirituality.

Other authors (Hill \& Hall, 2002) argue that God image and its relationship with spiritual experiences must contain elements of the sacred in order to break away from being only ideological. That is, they affirm that spiritual realities must be acknowledged and that God image must be understood in relational terms, "any search for the sacred is essentially a search for relationship” (p. 365). Additional support in the literature for the relational nature of God image was set forth through a comprehensive review by Hall and Brokaw (1995) that concluded, “God image is relational in nature, and comprises part of an individual's internal representation of the world” (p. 377). Thus investigating people’s perspectives of God image will provide a useful relational framework for understanding their perceptions of spirituality in general. Specifically, it is hypothesized that if God is viewed in personal terms (such 
as a father figure), then the accompanying perceptions of spirituality will have a relational theme. If descriptions of God evoke positive expressions of love and warmth, then descriptions of spirituality will likely have highly positive emotional representations. However, if God is perceived as a detached entity or as a substance filling the universe, then perceptions of spirituality will likely be vague and not well articulated.

Quantitative Measures of Spirituality

Up to this point, this literature review has covered differing theoretical perceptions of spirituality. It is also important to show the differing conceptualizations of spirituality that have been derived through empirical research. To capture and evaluate the essence of spirituality, researchers for the psychological study of religion and spirituality have created dozens of different measures (for a comprehensive review see Hill \& Hood, 1999), each with its own conceptualization of spirituality. The following section will briefly review published measures of spirituality and describe the implicit definition of spirituality inherent in the instrument.

Index of Core Spiritual Experiences (INSPIRIT). This seven item measure was created to identify spiritual experiences in a concrete fashion. According to Hill and Hood (1999), the core spiritual experiences are

(a) a distinct event and a cognitive appraisal of that event resulting in a personal conviction of God's existence and (b) the perception of a highly internalized relationship between God and the person (i.e., God dwells within and a corresponding feeling of unity or closeness to God). (p. 360) 
Thus the INSPIRIT emphasizes the cognitive and relational aspects of spirituality that are relevant to real life experiences.

The Mysticism Scale (M SCALE). The self-report function of this instrument is designed to assess intense experiences, “characterized by a sense of unity with the outside world and/or with 'nothingness,' which may or may not be religiously interpreted” (Hill and Hood, 1999, p. 363). The M SCALE addresses phenomenological aspects of mystical experience in the following areas: loss of self, perceptions of oneness, perception of all objects as animate, distortion of time and space, perceptions of special knowledge or insight, difficulty with articulation, experience of peace or bliss, and perceptions of sacredness or wonder.

Spiritual Assessment Inventory (SAI). The SAI consists of 43 items and measures adult spiritual development and/or spiritual maturity with both object relations and a contemplative spiritual perspective in mind. It bases spiritual maturity on two dimensions, equality in the person's relationship with God and awareness of God in their life. In addition, there are five subscales that include awareness, instability, defensiveness/disappointment, grandiosity, and realistic acceptance. Hence, the SAI stresses the relational aspects of spirituality.

\section{Spiritual Themes and Religious Response Test (STARR). The STARR} instrument is projective in nature and is based upon the Thematic Apperception Test. The test uses 11 stimulus cards that target the conscious and unconscious aspects of religious experience that include relational and representative associations with God. It also examines, "religious institutions, nature of the world, life themes, religious symbols, prayer and dependency” (Hill \& Hood, 1999, p. 372). Thus, the STARR 
approaches the study of spirituality through a multidimensional lens accounting for relational, intrapsychic, and existential aspects of spirituality.

Spiritual Well-Being Questionnaire (SWBQ). The SWBQ also uses a multidimensional approach to looking at spiritual growth and maturity. Furthermore, it examines the relational components of spirituality that include God, self, community and the environment. The extensive 82-item instrument is considered quite comprehensive and in addition to its examination of the developmental and relational components of spirituality, it studies social attitudes, beliefs, opinions, experiences, etc. According to the author the instrument is designed to be more of an "indicator or reflector of spiritual well-being rather than a measure of it” (Hill \& Hood, 1999, p. 375).

Spiritual Well-Being Scale (SWB). The purpose of this psychological scale is to act as a "general measure of the subjective quality of life. It serves as a global psychological measure of one’s perception of spiritual well-being” (Hill and Hood, 1999, p. 382). The 20 item instrument is considered holistic and looks at overall indicators in both religious and existential well-being. The test does not focus on spiritual maturity and it involves "transcendence by focusing on well-being in relation to that which lies beyond oneself, understood in two senses, religious and existential” (Hill \& Hood, 1999, p. 382). The test purports to study the psychological as opposed to the theological dimensions. In short, the SWB looks at intrapsychic, transcendent, and existential aspects of spirituality.

Daily Spiritual Experience Scale (DSES). The DSES is designed to be ecumenical and for use across many religious beliefs. The scale purports to measure 
spirituality at the experiential, contextual, and phenomenological level in addition to the experience of the transcendent.

Holistic Spirituality Scale (HSS). The HSS was created with the purpose of integrating three related areas of spirituality: faith, hope, and love. The theoretical belief is that the HSS will give researchers an alternative that measures on the multidimensional level versus examining each spiritual construct separately. Therefore, the HSS emphasizes spirituality at the multidimensional level specifically looking at relational, existential, and theistic components.

In summary, this review of various measures of spirituality, coupled with the wide array of theoretical descriptions reviewed earlier, demonstrates the complexity, multidimensionality, and differing perspectives of spirituality that are found within the psychological literature. In most cases, spirituality is discussed and measured without reference to Deity. This separation is surprising given the argument by Hill and Pargament (2003) that "To know God is, according to many traditions, the central function of religion....and...the connection with God is of ultimate value” (p.7). The Need for a Qualitative Approach

Much of the published research in psychology that has examined spirituality and religion has been quantitative, following the predominant empirical tenets popular in the profession. Gorsuch (1984) noted the success the field of psychology has had with quantitative approaches to the study of religion. However, he warned that relying on these successes has its potential "banes" (being blind to emerging research methods). Spilka et al. (2003) also observed that "although quantitative methods have been typical of data collection and analysis in the sciences as well as in the psychology 
of religion, there is no doubt that they miss something” (p. 13). Increasingly, researchers argue that the study of religious phenomena should include qualitative approaches. Paloutzian and Park (2005) maintain that "allowing quantitative and qualitative methods to complement each other holds promise for the development of exceptionally rich theory...” (p. 13). Other researchers make the assertion that some aspects of spirituality cannot be evaluated through quantification and that we don’t need more measures (e.g., Hill, 2005). Indeed, quantitative instruments introduce a host of difficulties. These researchers insist that qualitative research can better capture the dynamic qualities of religion and spirituality (Hill \& Pargament, 2003). The study of individuals' perceptions of spirituality and God image through a qualitative lens should enhance understanding of these important topics. Purpose of the Proposed Study

The purpose of the present study is to investigate individuals' experiences and descriptions of spirituality as they relate to their descriptions of Deity (God image). The specific research questions to be addressed are (a) how do individuals describe spirituality? (b) how do individuals' describe Deity? and (c) how do individual's descriptions of spirituality relate with their descriptions of God? In responding to these questions, it will be important to ascertain peoples' perspectives and perceptions; therefore this study will use qualitative data and analyses. Specifically, interview transcripts inquiring about different aspects of spirituality (descriptions of spirituality, including favorable and unfavorable aspects of spirituality, and perceptions of Deity) will be examined using hermeneutic methodology. 


\section{Method}

\section{Participants}

Participants were 63 adults living in Vermillion, South Dakota. Participants consisted of nearly equal numbers of women (51\%) and men (49\%). Ages ranged from 18 to 75, with the average being 37.5 years old. Across all participants, 62\% were married, 25\% were single, and 13\% were divorced or widowed. Religious affiliation was 31\% Latter-day Saint, 24\% Roman Catholic, 19\% Protestant, 14\% Christian, non-affiliated, and 12\% from a variety of other religious backgrounds (i.e., Buddhist, agnostic). The majority of participants (84\%) believed in God or a Supreme Being, with 8\% believing in an impersonal essence, and 8\% considering themselves to be agnostic or atheist.

\section{Procedures}

Participants were recruited through flyers placed in local businesses and religious organizations. Religious leaders were also invited to announce or print in their bulletins information about the study. Participants received a $\$ 15$ incentive for participation. They completed an informed consent form and were involved in a face to face structured interview with an undergraduate or graduate research assistant who had been trained in research interviewing.

Interviews consisted of several questions on spirituality and religious participation and generally lasted from 40 to 60 minutes. All interviews were recorded and transcribed. For purposes of this study, participants' responses to the following six questions were analyzed: 
1. What are your beliefs about the existence of a Supreme Being, Creator, or God? (If they believe in the existence of God, then the following three questions were also asked.)

A) What is God like? (attributes/character?)

B) How does God view you?

C) How would you describe your relationship with God?

2. How would you describe spirituality?

3. What role, if any, does spirituality play in your life?

4. What things do you do, if anything, that you consider spiritual?

5. What aspects of spirituality, as you understand it, are least appealing?

6. What do you believe are the primary reasons that you hold the spiritual beliefs you do?

\section{Data Analysis}

The philosophical underpinnings for the present study are based in the reflective and existential ontological premise of our will to understand within a relational framework. Specifically, meaning exploration is undertaken in a manner similar to that of analyzing a poem or novel (Jackson \& Patton, 1992). Relevant to this is the epistemological premise based on philosophical hermeneutical analysis that posits

Understanding is not, in the first instance, a procedure or rule governed undertaking; rather, it is a very condition of being human. Understanding is interpretation.[...] Second, in the act of interpreting (of "taking something as something”), sociohistorically inherited bias or prejudice is not regarded as a 
characteristic or attribute that an interpreter must strive to get rid of or manage in order to come to a "clear" understanding $[. .$.$] understanding requires the$ engagement of one's biases. Third [...] meaning is negotiated mutually in the act of interpretation; it is not simply discovered. [...] Finally [...] understanding is "lived” or existential (Schwandt, 2000, pp. 195-196). Transcripts of the 63 interviews were data for analysis in this study. Data analyses focused on the meaning derived from the data using hermeneutic analysis (Kvale, 1996). Managing the data from the transcripts was done using the software program NVivo, a statistical software program designed for use with qualitative analyses (Gibbs, 2002). Once the data were organized, the following steps were implemented:

1. Conducting an unfocused reading of the text to gather meanings (Jackson \& Patton, 1992; Kvale, 1996). This consisted of reading through the transcripts without trying to establish any a priori assumptions about the meaning, but rather to get a sense of phenomenon being described. It was not until after all of the transcripts were read through in their entirety that initial impressions were recorded. These relevant concepts raised by the participants in the interview were identified, labeled, and assigned a free node in NVivo.

2. Rereading of the text while constantly comparing between the parts and the whole to gain deeper understanding with each reading (Kvale, 1996). Once an initial array of ideas was noted then the text was read and reread several times in its entirety as well as by question. Notes were jotted on a white board and ideas were kept or rejected through the process of part to whole analysis of the text. As new categories 
emerged, relationships were examined and assigned parent or tree node in NVivo. My own biases and ideas were tested against the text (more on this later) to challenge thematic findings. Through this process, themes became more apparent and the micro/macro examination revealed the phenomena and perspective of the participants.

3. Using language as opposed to numbers to describe the thematic findings (Kvale, 1996). Realizing that the whole-part reading could go on endlessly, the analysis was concluded once it was felt a saturation of ideas had been reached. After identifying the themes, quotes were identified and used to describe and support the themes. Themes taken from the data were used to build a conceptual framework for describing individuals’ perceptions of spirituality, relationship with God or God image, and the corresponding relationship between the two.

Peer review. To increase the integrity of the findings, a random selection of one third of the transcripts were extracted from the total pool using Excel to perform a sort and a random selection. While the qualitative analysis was performed by the principal author, one third of the interviews and the interpretations were given to a colleague trained in qualitative research for peer review. The reviewer was a graduate student in counseling psychology unfamiliar with the data but experienced in qualitative analysis. The peer reviewer read through the transcripts to develop his own initial familiarization with the data. Next, the peer reviewer examined the transcripts again, this time explicitly evaluating the interpretations outlined by the principal author. The object of this review process was to get at a consensus of believability and validity of the interpretation of participants accounts. The basis for this peer review has been articulated by Bruner (1986): 
With science, we ask finally for some verification (or some proof against falsification). In the domain of narrative and explication of human action, we ask instead that, upon reflection, the account corresponds to some perspective we can imagine or "feel" as right...the aim....is that the hypotheses [or theories] fit different human perspectives and that they may be recognizable as "true to conceivable experience” (p. 51-52).

The principal author and the peer reviewer then met to discuss interpretations looking at areas of agreement and disagreement. While there were no major disagreements on themes, a different set of eyes and an added level of perspective proved to be useful by focusing on consensus along with tightening and consolidating of themes. The resulting interpretation of the data was then reviewed by a faculty member (dissertation chair) for discrepancies. Again, one third of the transcripts were randomly taken from the pool and given to the chair. Three meetings were held to discuss differences and to extract any new ideas. Ideas were refined, discussed, and incorporated for purposes of internal consistency as a final step of refinement prior to full committee member review at the oral defense of the dissertation.

Reduction of analytic and interpretive bias. My worldview and experiences are shaped by my LDS religion, European American ethnicity, middle class background, male gender, geographical residence, etc. My experiences and background influenced the way in which I viewed and interpreted the data. In addition, the anthropomorphic attributes that I ascribe to Deity and my belief about spirituality being primarily relational in nature, likely played a role in the analysis. I was aware of the danger in viewing my own experiences as normative and others' 
experiences as unique. Therefore, my best defense against permitting my biases to unduly influence the analysis and interpretation was through acknowledging and maintaining an awareness of them. Specifically, I undertook four additional steps to help keep my biases at the forefront.

First, prior to any analysis of the transcripts I went through and answered all of the questions myself. Like the participants, I verbally gave my answers as if I were being interviewed. This self-interview was recorded and my answers to the questions analyzed. The main themes I extracted from my own responses to the questions were that I described God in more superficial terms but with human-like characteristics, spirituality was something that is not necessarily tied to religion (one could feel spiritual out in nature), spirituality is relational, and that there was a "works" or “doing” component to ones advancement of spirituality. Later on, comparing personal responses to the findings of participants led to some surprise findings as well as some that fit my own worldview. For example, the realization that some participants could describe God more deeply through their experience and that religion played such a high role in spirituality were unexpected. I found myself wanting to turn a blind eye to some of the findings like the "doing" and "relational” nature of spirituality. I also found myself being extra careful with LDS participants (while the participants and their religion were not stated, it was obvious from some of the answers as to their affiliation). I do believe by being attentive to this it helped me to look deeper and make sure that the themes were really there.

Second, since the data was archival and the participants were predominately of Christian persuasion, I conducted additional interviews with others not of the Christian 
faith. Rather, I contacted five people of Muslim, Hindu, and Buddhist persuasion to help contrast my own views and to assist in thinking outside of my own experience. This process involved an informal discussion of the questions and not all of the questions were asked. Some of the ideas generated from these conversations (not included in the analysis) were the self-actualizing nature of spirituality, spirituality as a path, God as essence, spirituality as one's own mind or conscience, experiential nature of spirituality, and a least appealing aspect of spirituality being religion. This process led to the recommendation in the future directions portion of this study to replicate it using participants affiliated with Eastern religious views.

Third, I read a college text on world religions (Palmer, 1997) to better understand the worldviews of other religious traditions.

Finally, as outlined above, I used a peer reviewer trained in qualitative analysis to check my results. Furthermore, my dissertation chair assisted in the checking processes, and committee members served a key role in raising my awareness of my biases. 


\section{Results}

The present study set out to describe (a) individuals’ perceptions and descriptions of spirituality; (b) participants’ perceptions of God image; and (c) how individuals’ descriptions of spirituality relate, or don't relate, with their descriptions of God. The results of this study were obtained via the hermeneutic interpretive steps outlined previously and are described in this section. Coded surface themes were also gathered and are included separately in Appendix B of this document.

\section{Perceptions of Spirituality}

The first area of inquiry involved participants’ descriptions of spirituality. Six central themes came about from the analyses:

(1) Participants used abstract language when defining spirituality

(2) Participants viewed spirituality in terms of their own or others' religious beliefs

(3) Participants often held extreme views regarding the role spirituality plays in their lives

(4) Participants described spirituality in terms of extraordinary experiences not typically experienced in day-to-day living

(5) Participants' descriptions of spirituality frequently involved relational language

(6) Participants (predominantly Christian participants) described spirituality in terms of doing rather than being

Used abstract language. Although most all of the participants in this study had something to say about spirituality, the responses were varied, multi-dimensional, 
and in a majority of cases were abstract. Participants often spoke of what spirituality is not. When they did attempt direct descriptions, they often used metaphors or similes, a non-literal use of a figure of speech to suggest resemblance or likeness to something, (see Lakoff, 1980). Often it was as if they did not have the language/terminology sufficient to describe what they believed or experienced. The following three responses from different participants illustrate both the vague and abstract representations used in describing spirituality:

Spirituality. Hm, I guess-I guess I don't know if I really understand what spirituality really is. I guess, maybe in my feeble way of thinking about it, it's probably prayer uh, it's-it's-it's acknowledgment of God being there, a Supreme Being, and the acknowledgment that uh, He needs to be honored and glorified, uh. That's as much as I can determine what spirituality is, in my way of thinking.

Spirituality is, it's like the air in the sky, it is like the wind on a day that is windy and you cannot see it but it's there, you see the grass and the green trees and you see things growing, like, but you don't necessarily understand how and why all those things are green or grow or why the ocean is...looks a certain color on a certain day or another day it looks a different color. To me, spirituality is like an inner essence and it doesn't necessarily mean that we can understand it all.

I know a lot of people go to church and believe God says this, Jesus said this and da-da-da, but spirituality for me is being aware of the energy and living life by uh, the belief that the love I give is the mark I make of my life, this is what matters. And basically, all the other stuff is necessary to survive in this physical place that we are, but uh, you know, it's like wear your shoes outside if the cold gets to you, you know, it's-it's a necessary thing but it isn't what it's really about.... I guess paradox, if you want to call-call it that, the more I've learned about that the less I understand, and I guess it doesn't bother me anymore.

Based on own or others' religious beliefs. While not all participants'

perceptions of spirituality were grounded in religious beliefs, many individuals used religious experience and traditions to frame their definition of spirituality. 
Interestingly, even many of those purporting that spirituality had nothing to do with religion used religious terms to articulate what spirituality was to them, usually by way of contrast. Participants holding orthodox religious beliefs rarely made distinctions between religion and spirituality; the two concepts seemed indistinguishable in comments by religiously orthodox participants. Moreover, participants, such as the following three, who identified with a monotheistic religious tradition conceptualized spirituality in terms of their belief in God:

[I] guess someone who is strong in their beliefs, spirituality would be strong in their beliefs with God, they pray and they feel like they have a loving relationship with God and that God helps them. I guess that's the best way to describe spirituality. Maybe church is involved there, too.

Spirituality [...] I think stems from a belief in God. [I] think spirituality has to do with the laws of God and following those laws. I have a hard time with people who say they're religious but they don't really follow any religious values and, but you might say, they think that they're spiritual. I think being spiritual is maybe being a little more obedient to the laws of God [...].

Spirituality, that's a tough one. Number one, it has nothing to do with religion. Religion I believe is man's way, it's just a vehicle to help us to be spiritual. Spirituality is a personal, and yet a growth process but it's not personal overview of living a bad day's life. My spirituality is my relationship with my Lord; it's my education process, learning what He expects of me and how $\mathrm{He}$ expects me to live and is based on my relationship. I think it's based on scripture and wisdom, but it's my basis for living, it's my way of life and it's based on living in this life.

Held extreme views. Many participants saw spirituality as being central to their identity and way of life while others reported that spirituality played little or no role in their life. Responses supporting both ideas include, "I'd say spirituality gives me the basic framework that I try to hang things on or work around," "My spirituality is at the core of my being," "My existence [...] if I sleep and I wake up in morning, it's the way of my existence," "It's how I view myself in this universe.” At the other end 
of the spectrum, "I would say [that spirituality plays] about $5 \%$ in my life. That's all, I mean, I don't believe in a lot of things in terms of spirituality... it's just a matter of looking at things logically,” "It's not real significant. When I'm in the garden I think spiritual thoughts, when I'm not I don't think about it a whole lot.”

Defined as extraordinary experiences. Not directly articulated in this fashion, but implied in many of the responses, was the idea that spirituality is enrichment or changing of ordinary experiences to extraordinary. Responses to the questions about spirituality typically fell within one of the following four sub themes:

(1) Spirituality gives additional strength to overcome life's difficulties

(2) Spirituality is a higher journey or pathway to something greater

(3) Spirituality is enriched feelings

(4) Spirituality is connection with God at a higher level.

The following responses illustrate, "I think my spirituality is what gets me through it [adversity] and helps me make the decisions that I feel that I need to make and to hold strong to those," "Spirituality I think is being able to look beyond your daily life and tasks...it's a journey to perfection, the perfection of life.” The following personal experience with spirituality illustrates the transcendent nature of the spiritual feeling:

I can tell you the day and the time when I had my conversion experience. It was a Thursday evening about 6:45, October 26, 1986, and I heard the words, "Jesus Loves You," and they were as clear as the words you're speaking right now. It's what they call an interlocution, it's like a voice, an inside voice, it is loud, it's spoken, human conversation, and along with it came an incredible love, it's just a peace that transcends everything. I remember looking at the people around me, I was in a group of about 12 people at the time, and I just had so much love for each person I was in tears, and I saw the beauty of each 
person. For a couple of weeks after that I was walking about 3 feet off the ground. It was amazing.

Another example of this theme comes from the following response from a different participant: "Spirituality is being able to commune with God with our spirit, the deepest part of our spirit is communicating on that level.”

Relationships significant in descriptions of spirituality. One central aspect in participants' descriptions of spirituality was the notion that spirituality has a relational component. While it was expected that a relationship with God would be central in monotheistic traditions, even other participants (agnostic, Buddhist, etc.) described spirituality in terms of relationships. These relationships were with nature, friends, and community, such as in the following quotes from different respondents:

I want to feel that connectedness with all essential beings and to feel that connectedness even to those who are, you know, being really cruddy to me, and those who are harming other people and have seen suffering, even those who are the cause of suffering I would still like to be able to see my connectedness with it.

Spirituality is the degree with which you have a oneness with God; it's the ability of human being to grow closer to God and to emulate those good qualities that God has and to, you know, to develop a communication with God so you can have that oneness.

Other participants said, "It's being with my children, or animals or trees, or natural experiences, and just shedding all that daily life," "Closest I can come to feeling spiritual and feeling like there's real devotion [...] there's [is] just in my relationships with women and close friendships.”

Viewed in terms of doing rather than being. An additional theme from individuals' descriptions of spirituality that emerged was in relation to how participants responded to the question of what things they did that were spiritual. 
While a handful of participants described spirituality in terms of sitting and meditating, mindfulness, or sitting and watching the birds for hours, the majority of respondents, especially those inferred to be of a monotheistic religious tradition, identified spirituality as something they did, or things they needed to do, to cultivate whatever they ascribed spirituality to be. This typically involved religious activity such as reading scripture, praying, attending church, or performing service, "I pray all the time. I'm talking to God, to Jesus, the Holy Ghost all the time," "[I] pray fervently, and often, and I do that anyway, for, also time spent with God is kind of the pipeline of spirituality," "Reading the Bible is stimulating. Thinking about it, there's some spiritual things in there [...] I find a lot of spirituality in the New Testament," "We have our church services and we have a number of opportunities throughout the week in my church to provide service to other people.”

Spirituality was also viewed in terms of developing one's moral character and in displaying appropriate and dignified behavior becoming of one’s spirituality, "I try to represent my spiritual beliefs through my, what I do, how I behave, um, I try not to say cuss words, I try not to do things that people would judge being uh, poor behavior," "I think playing a game with my son is spiritual, going out and having 'catch' can be spiritual experience because it can show love towards each other and I think when you're doing that, kind of gives that spiritual feeling," "I treat people the way I want to be treated, I guess, most of the time. I mean, at least spiritual...I mean, 'what goes around comes around,' is how I feel. I feel if I give 95\% - at least $90 \%$ of myself, it's going to come after me.” 


\section{Perceptions of God}

Participants described a variety of ways in which they perceive God.

Specifically, the following six themes emerged:

(1) Reported experiences with God led to more concrete perceptions of Deity, whereas descriptions without a personal sense of experience were more abstract and characterized by adjectives

(2) Participants’ religiosity clearly influenced descriptions of God

(3) Participants' descriptions allude to a gap between themselves and God that creates dissonance

(4) God is more relevant in time of need

(5) God is viewed in gender specific terms

(6) Overall God is viewed in mostly favorable terms

Experiences with God led to richer perceptions of Deity. Deeper more reflective descriptions of God were influenced by direct experience with God in a variety of ways and whether they had been a partaker of God's generosity and mercy or through their own role as a parent. Consider the following quotes from three different interviewees:

Growing up as a youth I used to think of Him as being not really a person, just something of Deity that was everywhere, you know, that oversaw everything that was in charge of everything that happened. Now that I've grown older, now that I've put more purpose and meaning and understanding into my religious beliefs, I believe that He is a Human Being such as you or I, Someone who is probably very Fatherly or Grandfatherly, when, someone I can go to and know is on the other side listening to me as if I were speaking face to face. I feel that He answers my prayers, not always in the way that I want Him to, but that answers do come, and that if I'm in-tune with the Spirit, the Holy Spirit, that I realize and recognize those answers. And I think of Him as a Person and Human Being who probably experienced, definitely experienced 
somewhere along His life things very similar to what I'm experiencing here on earth and gives purpose to why I'm here and where I'm going.

I believe that God is all-powerful, all-knowing. I believe that God knows my thoughts, my intents, I know God knows me better than I know myself. And I truly believe that He loves me and He is concerned about me because since I am, since I believe that I am literally His son, see, I can't comprehend the love that He has for me, I know He loves me more than I love my son, which is hard for me to comprehend, because the love that I have for my son is tremendous and the way I want my son to succeed in life is the way that God the Heavenly Father wants me to succeed.

He's loving, He's forgiving, He gives us free-choice of wanting to believe in Him or not. He doesn't demand of us, so He gives us some free-rein there. Um, He's sacrificing in the respect that He gave His only Son for us, and I think about that with our own children. He gives us many gifts. I mean, He's a very giving God. He gives us many gifts of our children, whatever possessions we have, things like that. I do think that um, He hurts when we do wrong, I think that we can't even begin to understand what that's like, the pain He must feel when we sin against Him. I don't think we can even understand it. It's just completely, completely intensified compared to what we feel, in a sense of physical pain or emotional pain.

The second type of descriptions sharply contrasted the richer descriptions given previously. These perceptions were void of personal experience and were more abstract in their descriptions, "Well, basically kind I guess, loving, and all-knowing, merciful, forgiving, caring, there may be others but I guess those are the ones that come to mind immediately," “He's all-just, all-knowing, all-forgiving. That'll probably be it," and "Merciful and fair and loving."

Religiosity plays a role in describing God. While some participants left out religion entirely in their descriptions of God, many of the participants referred to religious beliefs as a starting point to describe what Deity is to them. Examples of responses from various religious persuasions illustrate this theme. First, "Well, I certainly believe in God and as a Catholic I believe in a trying? God, the Father, Son, 
and the Holy Spirit. I believe that God created the universe, He created all of us.” Another said, "I subscribe to the Buddhist philosophy so it's not theistic. They - there are, I guess I have to practice this, there are many God-Goddess like figures, but They aren't out there, They are manifestations of what this part of us.” An inferred Muslim participant said,

He's cool. He or She is cool! Again, that is based on things that I've learned or read from a Holy Book, you know, you can't, because like for the most things, you, God is not, it's not like a Christians where, you know, they have a lot of movies about God and they show you that God is a Male and all that, so you can tell, you can picture what It is, based on the Muslim religion, you just read in the book about God, where you just kind of believe, your belief is built on what you read and you know. [...] so you know God is forgiving, is the Almighty, He knows everything, you know, it's just anything, a mixture of everything.

A final example of this theme comes from a participant not affiliated with a particular religious belief: “And so, my version of God pretty much is the same as the Bible. Someone, Something, I don't know, would forgive and wouldn't judge, and yeah, that's it. Someone good!”

Gap between participant and God creates dissonance. An emergent theme throughout participant responses, especially those of a monotheistic persuasion, was the idea that there is a gap between themselves and God. This was the case for a variety of participants and it came about in one or more of the following perceptions:

(1) perfection and works

(2) perceived deficits in themselves

(3) an mirrored/inverse view of God in relation to themselves

(4) God can’t be known

(5) if God is good why is their suffering. 
First, many viewed their relationship with God as dependent upon their own level of personal perfection or to the degree that they could produce good works. Those participants more orthodox in their religious views also placed more emphasis on works, "He created us in His image and by sin we have fallen from that and only He can put us back together again, and we'll always fall short of perfect love of God The Father. We can just continually work toward that.” Two additional participants shared their view of God's conditional nature:

I believe that you have to make good choices and you're accountable for whatever kind of choices you make and that God is pleased with you if you are making good choices and He doesn't love you if you don't, but He's probably disappointed if you don't make good choices.

I believe that He's judgmental to the point that if you refuse His teachings and His beliefs then He will refuse to accept a place for you in the Kingdom to come. I think He's judgmental to that point, and I think trustworthy, merciful, loving, kind, all that good stuff.

Second, and somewhat related to an emphasis on works, was the tendency for many participants to view God in terms of what they lacked or what they themselves were not doing. Participants with concerns about their deficiency would state that they had a relationship with God, but that it was not as good as it could be because they did not go to church, read scripture, or engage in religious activities. Perceptions of this nature included thoughts such as "I think for the most part, my relationship with God is good. I sometimes don't pray enough or I don't take all the sacraments...I still think I'm not doing enough.” Another participant said,

It's probably not as well as it should be, or could be. I probably could go to church and learn more or sit you know, and read a Bible and stuff like that, to learn more about this type thing. [...] If I were to go to church on Sundays and stuff, I feel like I would have more of a personal relationship with Him. 
Third, some participants perceived this gap between themselves and God to stem from an inverse nature inherent in their relationship with God, God has "supreme intellect” and He views me as “probably kind of ignorant”, or “God is big” and God views me as “small.” However, the most common contrasting element or subordinating position to God was the parent-child view of themselves in terms of

God. While this was often reported in favorable terms in some cases it was not:

In my religion I'm taught that God treats us like His children, and He loves everyone of us, so I guess that's how I think. I don't know if I appreciate being treated like a child, now that I'm so old. No matter how old I am He's always going to treat me as a kid.

Fourth, the perception that God is a mystery, is unfathomable, and has such supreme attributes that are beyond mortal comprehension was shared by participants who would state ideas like “I’ve thought about it [God's dealings] before, but it leaves me, leaves my mind smokin," "I think God is unfathomable," “God is sovereign...He remains somewhat of a mystery.”

Fifth, there is a perceived paradox in the nature of God that leads to dissonance:

It's kind of hard to say. Sometimes I think He's fair and just and everything and sometimes it's kind of hard with all the problems in the world and sicknesses and diseases and what have you that it's, it's kind of hard to really believe that He's a true and loving God if He does let everybody suffer from diseases and the different problems in the world. A lot of the problems in the world are man made but there's...it's a hard question...that's about it.

Finally, participants countered this dissonance or perceived deficiency through perceiving God as forgiving, loving, and patient with them, as in the following three cases: 
I feel that He's very patient, because I've had rough times too, and impatient times, and sometimes I've gotten angry with Him, you know. Unfortunately, I admit that and I know that even though I've gotten angry with Him, He does forgive me, and uh is patient with me.

I see God as very powerful, very patient, He's gotta be with the kinda human beings we are. Um, omnipotent, um, kind, gentle, um, loving, very parent-like.

He's not always happy with the things that I do but He still loves me and is guiding me along the path so I can improve and grow.

God is more relevant in time of need. While it was expected that participants would view God as a source of help, some participants viewed Deity as only relevant in time of need, “They are really there when you need them. It's like they are there and uh, They don't show up, but when you need them. [...]” Two additional participants said,

I believe there is God existing on the earth, and uh, sometimes I really believe it when I feel troublesome, and or worry about something, and uh, I wouldn't, you know, just spiritual uh, support, like when I feel sad or I want to try to do something that I will, you know, pray and I hope that I can do that, although I am not a, you know, a formal member, but I just think that maybe if I pray they can help me to go through the problem or something, yeah.

If you have trouble and need anything, you can just pray and..., so every time... One time I was in the Emergency Room, I was really really scared, and uh, I got really sick, and, my mom is not here, is not here, and my father was not here, either, and I only have my friend, and uh, that time, the only thing I holded and prayed was that thing, because it's from my mother and, I think, you know, it can help me, and so, I become like, whenever I have problem, I will pray. I don't pray, you know, everyday, just whenever I have problem I pray, and I hope He can help encourage me and support me. So, that's the way between us.

God is viewed in gender specific terms. One overarching theme in participants' views of Deity was that the more concrete the description of God and when viewed in Christian terms, God was primarily a male figure. Exceptions to this were participants from Eastern religious traditions and a couple of participants who 
felt that Deity resembled more characteristics of womanhood. The following direct quotes illustrate views of God in terms of a fatherly role, "He’s our Heavenly Father,” “Very Fatherly or Grandfatherly.” In addition, God was also inadvertently referred to as male gendered when many participants were describing their beliefs about God, "I believe that God created the universe, He created all of us," "Well, He's all-knowing, all-powerful, omnipresent, He is love.”

God is viewed favorably. Finally, when it came to perceptions of God the overwhelming support was the view of God in a favorable light and in positive terms. Of course, there were a few exceptions to this and it did not apply to those who did not believe in a Deity, but the evidence clearly supports a favorable view of God with comments such as “He created everything beautiful and that's what He is, just everything beautiful,” and “He is an all-loving Person, He loves everyone, no matter what they've done and He cares for everyone.”

\section{Correlation Between Perceptions of Spirituality and Perceptions of God}

The final task of analysis involved comparing individuals’ descriptions of spirituality with God image. Six themes emerged, four directly comparing the two constructs and two holistic themes that applied to both spirituality and views of God:

(1) Participants found it easier to describe God than spirituality, although both were difficult to describe

(2) Perceptions of spirituality were uniquely different when God is not viewed in anthropomorphic terms or is not viewed as relevant

(3) Participants' perceptions of spirituality and perceptions of God were consistent within an integrated belief system 
(4) Greater abstract views of God led to less personalized descriptions of spirituality

(5) Participants viewed religion as the culprit for any negative perceptions rather than spirituality or God and

(6) Superficial exploration of beliefs in God and perceptions of spirituality were often deemed sufficient.

Easier for participants to describe God than spirituality. An interesting finding, although not a surprising one given the abstract nature of spirituality, was that participants had greater ease in describing their view of God compared to their description of spirituality. The following two pairs of responses are exemplary: (1) Description of God: "I believe that there is a God, that He is aware of us and that we are children of God. I believe that He is an actual Personage, that He is a higher being, more knowledgeable than we are and He is loving and just. (1) Description of spirituality: “To me it’s something that is a part of your life, it’s not something...lifestyle is something that influences you, choices, how you act and how you behave, you do something that needs to be kindled....” The next pair was (2) Description of God: "I believe in God. I believe He has a physical body and that He created me and that He is loving and understanding. He is always there when you need him.” (2) Description of Spirituality: “Guess it’s kind of an inner feeling, or, I guess, it could be some action that you do, but spirituality is just an inner peace, inner knowledge of whatever you think religion is, I guess, who you think God is.” Differences when God is not viewed in anthropomorphic terms. Perceived differences between spirituality and perceptions of God emerged when those affirming 
a belief in Deity from a monotheistic tradition contrasted to participants claiming to be of Eastern, atheistic, agnostic, or scientific persuasion. When participant responses were examined, the following three sub-themes emerged:

(1) Spirituality is viewed as less conditional and more relative among participants not ascribing to a monotheistic view of Deity

(2) Spirituality acts as a moral or guiding compass in the absence of a belief in a monotheistic God

(3) Spirituality, when not associated with a Deity, is more of a subjective and internally focused phenomena.

First, participants not of Western traditions described spirituality in more relative and less rigid terms. They viewed spirituality in independent and subjective terms, "I just feel spirituality as anyone can be with just accepting things as they are," “If some person they want to practice some spirit community, it’s up to them, it's not my business...I don’t like to press on people and share my opinion,” "I believe different people have different spirituality and they would do different things in the same situation because we have different spirituality.”

Second, without a clear description of God or a belief in a anthropomorphic Deity non-religious participants saw spirituality more in terms of a value system, a sense of morality, and a way or script for life, “I don’t believe in God, but I do believe in the values that are like under Him," "Spiritual things are like moral things...I stick to the values," "Spirituality is just like a feeling when you do something, it's the way you are describing, the way I feel things will be, the way I'm doing things, you know, you stay in the ways, spirit way you act and think.” 
Third, participants who did not associate their descriptions of spirituality with the idea of Deity reported that spirituality was an internal, introspective phenomenon. The following quotes exemplify this concept: “It’s more introspective looking for answers," "Spirituality is most innermost in our minds, in our bodies," "We should have a spirit belief in the heart.”

Consistent perceptions within an integrated belief system. Among participants who believed in God, their descriptions of God and their descriptions of spirituality were characterized by a high degree of consistency. For example, if participants spoke of God in relational terms then their definition of spirituality had a relational flavor, “[God is] very parent like...I have a close relationship” matched with "I think spirituality is really a relationship with the Supreme Being.” Participants speaking about God in terms of His role as a guide also spoke of spirituality in the same manner, "He’s also there to guide us and help us live our lives" matched with "I would describe spirituality as...how or what I am going to believe and the decisions I'm going to make.” Participants describing God in terms of an essence or God as incorporeal also spoke of spirituality that way, “[God] like an essence” matched with "Spirituality is an intimate knowledge with that essence." Similar congruency was found across descriptions that emphasized beliefs, that emphasized love/feelings, that emphasized growth/progression, that emphasized nature, that emphasized conditional worth, etc. For example, if God is viewed as an authoritative/punishing figure the description of spirituality emphasizes compliance, “To me He is somebody who is standing up there, looking at you all the time... and I think He is up there to make sure we do what...He tells you to do" matched with "[Spirituality] things you are supposed 
to do, the things you are not supposed to do.” In sum, theistic participants were remarkably consistent in their descriptions of Deity with their descriptions of spirituality. Although there was diversity across participants (some emphasizing beliefs, others actions, others relationships, etc.), theistic participants in this study tended to use similar terminology to describe both God and spirituality. Their descriptions regarding God and spirituality appeared to be parts of a consistent framework most likely indicative of their general worldview.

Abstract God-less personalized descriptions of spirituality. Participants who were more specific with their definitions of a God and spirituality typically used more first person language (“I” and “me”) while participants less comfortable in their descriptions tended to report their ideas in more generalized terms ("people” "you” and “others”). The first set of responses below illustrates a personalized description of God followed by the corresponding description of spirituality. The second set illustrates a contrast to the first set with more abstract responses:

(1) Description of God: I believe that God knows my thoughts, my intents, I know God knows me better than I know myself. And I truly believe that He loves me and He is concerned about me...I know that He's there for me and He hears and answers my prayers.

(1) Description of Spirituality: I don't think you can be spiritual without having a relationship with God. So, I think being spiritual is something that is an action word. I think you've got to be actively engaged in spiritual things like prayer, would be something that would be an action, reading scripture is a spiritual experience, or help you to have a better spiritual aura. I think also, things like giving service or following the example of Jesus Christ, anything like that, serving others.

(2) Description of God: Well, I don't know. I couldn't tell you what He's like. I just know, I just believe that there is a God and if you follow the right path, if you go down the wrong road and do something wrong and you know it, you should be asking like forgiveness and confess your sins or whatever. It's not 
necessarily in church; you can be home alone and stuff and still ask for His forgiveness. He's probably got a long white gown on and long hair, I couldn't tell you. I'm stumped.

(2) Description of spirituality: Everybody has their own beliefs. There is not one certain set of, or one certain type of church. Every church is basically kind of different. Every church has their own beliefs. I have my own belief, you have your own belief.

Religion as the culprit for any negative perceptions about God or spirituality.

When participants described any negative experiences or perceptions during their responses to the questions, these were almost exclusively aimed at religion. This included abuses of power, bad childhood experiences, intolerance, and religious teachings that went contrary to their personal beliefs. Rarely did participants criticize beliefs about spirituality or God. The following quotes exemplify the denigration of religion by three participants who otherwise had positive descriptions of Deity and spirituality:

I'm struggling right now [about] with two of my friends [who] were kicked out of a church because of their being in a gay-committed relationship, and I struggle with those issues a lot. Um, I think that sometimes the church goes overboard, there's not enough forgiveness there, uh. They make up their mind on a Biblical sense that something is wrong, and-and there's no...it's either right or it's wrong and there's no great. Um, and I think the church tends to be that way. If it's not...if it's Biblical, the problem there it's okay if it's Biblical, but people tend to read things in to verses in the Bible, and take out of that what they-their own beliefs. And sometimes I think they hurt other people within the church based on that.

I stopped going to church when I was probably 12 or $13 \ldots$... used to be really involved when I was young, but the reason I stopped and not wanting to be involved was, we used to move a lot and I was always, we were always the "new kids," me and my brother, and going to Sunday School was just the worst being the "new kid," and I just didn't enjoy it and then I remember I was watching some T.V. show about, I think it was either China or India and they were talking about religion, I think it was China, at my grandmothers' house and my grandmother's really religious, and she said, you know, I said, she always made us go to church when we were with her, "Are those people going 
to go to hell because they don't believe in Jesus and God?" and I was probably 10, and she said, "Yeah," you know, and that was crazy, I thought, you know, and I thought, you know, I don't know, it kind of "turned me off," it, organized religion.

I do believe in God like I say, and, but I don't believe in a lot of the [religious] teaching and, and some of the rules and regulations. [I] don't believe in murder, don't believe in adultery, you know, I do swear and I do take God's name in vain, it's the Bible and whose interpretation is that and how did that interpretation come down and what have you, but it's-it's kind of hard to say, you know?

Uncritical exploration. Based on the responses of individuals, it appeared that in many cases they maintain consistent beliefs over time. Although some participants did report introspection and specific experiences that helped to solidify their beliefs, many individuals seemed satisfied with a cursory understanding of the concepts. In fact, some participants speculated during the interview what their beliefs would have been had they been born under different circumstances. It was also apparent that individuals’ credited the influence of their upbringing, friends, and community with shaping their beliefs. Participants made comments such as "Because that's how I was raised. My parents started taking me to church when I was very young, you know. I was confirmed in the faith they were, so, that's what I've come to believe,” “Gosh, I’d actually have to say the tradition of growing up in my family being [religion identified], all honesty," “Being brought up in one particular race in a country that is predominantly of that religion," "Because of my upbringing. That's how I was taught.” The next quote illustrates some of the participants’ wonderment surrounding how their beliefs might have been different had their circumstances been different: 
Think about if I were born in a different country I'd probably have a different belief. [In] some ways it seems kind of unfair, you know, I think about that. I think about my children but, but then, you know, in fairness I did try to wipe the slate clean and search out what I thought was, you know, and it brought me back to all the way back to "square one" so, I don't know how much influence that has. 


\section{Discussion}

The present study set out to describe individuals’ perceptions of spirituality, their perceptions of God, and any similarities or differences among these two constructs. Specifically, this dissertation was intended to contribute to the existing body of research and explore some of the perceived deficiencies in the field of psychology’s handling of the constructs of spirituality and God image, inconsistencies in definitions of spirituality, limited use of qualitative methods in exploring spirituality and God image, and heavy reliance upon classical theorists in conceptualizing spirituality. This study sought to glean insights through attending to individuals' perceptions and experiences. The resulting themes from the analyses provide interesting insights into the beliefs and perspectives of the 63 people who participated in the study.

\section{Overview of Results}

Overall, interpretation of the findings reveals that constructs without context, especially abstract constructs like spirituality, are limited in what they can capture. While classical and contemporary theorists in psychology will be considered later in this section, their work will show only limited overlap with the diverse accounts of spirituality reported in this study. What is clearly missing in the attempts of past studies to measure spirituality is the context in which these experiences occur.

Religion provides a framework for people to talk about spirituality and God. Given the imbedded nature of religious beliefs in the perceptions of God and spirituality to participants in this study, it stands to reason that religious belief provide the scaffolding in which the complex nature of spirituality and the Divine are given 
meaning and connected with individuals' worldview and daily experience.

Participants in this study describing spirituality without a religious base of experience to draw from provided more abstract descriptions of spirituality. It is apparent that interactions with other people and discussion about the topic yield greater capacity for language and concrete descriptions made relevant to life experiences. Each construct will now be examined in greater detail.

Perceptions of spirituality. Although participants' descriptions of spirituality were varied and multi-dimensional there were similarities that emerged from the data. Findings that were congruent with findings in extant psychological research and with common sense expectations included the following: Participants' identifying themselves with a Christian persuasion tended to identify spirituality in terms of actions/works (e.g., church attendance, prayer); spirituality was described with greatest depth when participants related extraordinary experiences; and participants commonly identified relationships with Deity, others, and nature in their descriptions of spirituality. Although these themes are already found in the current psychology literature, they do have practical significance. For example, among North American Christian participants in this study, notions of God and spirituality tended to be connected with expectations to perform certain deeds and a general impetus to acquire things spiritual. This observation seems reflective of Western culture in general and may be a classic example of how any system of beliefs/values aligns with cultural socialization. Another observation was that many participants discussed the enrichment they felt through transcendent experiences associated with these efforts in the way of greater capacity for feelings (love, well-being, etc.), a source of strength to 
draw upon, and greater relational capacities with Deity and others. These extraordinary experiences were described in singular terms, and it was clear that these experiences reinforced participants' interest in and interaction with things deemed spiritual.

Findings that were somewhat surprising in this study were the degree of abstraction in defining or describing spirituality, the extreme contrast among participants as to the importance of spirituality in their life, and the clear salience of religious beliefs to descriptions of spirituality. It seems surprising that participants would struggle to articulate what spirituality is, if it is indeed an important aspect of their experience and worldview. It was also surprising that religious ideas and ideals were so completely intertwined, given the common emphasis within the field of psychology (and in society in general) to distinguish religion from spirituality. This finding also contradicts psychology’s increasing attempts to remove notions of Deity and religion from definitions of spirituality (Zinnbauer, Parganent, \& Scott, 1999; Hill \& Hall, 2002).

Perceptions of God. As with participants’ descriptions of spirituality, perceptions regarding the nature of God were quite varied but did yield several commonalities as well. Themes observed within the data that were consistent with existing psychological research and common sense included religiosity clearly influences descriptions of God; God is more relevant in time of need; God is viewed in gender specific terms; and God is viewed in mostly favorable terms. While these descriptions seem rather intuitive, they illustrate worldviews that comprise strong religious beliefs and a favorable view of a God that is relevant to their lives. In many 
cases, the descriptions include a deeply intimate and familial reference to God as a Father.

Findings not anticipated were that participants’ often alluded to a gap between themselves and God that created dissonance and that participants' experiences with God seemed associated with more concrete descriptions of God, whereas descriptions without personal experience were more abstract/superficial and characterized by adjectives. These surprise findings have clear relevance to the field of psychology. Because many individuals viewed God as major part of their belief system, the presence of any kind of dissonance or lack of understanding/trust in God would seem to have implications for identity development and well-being. On the other hand, passivity and abstraction would seem to have equivalent implications for identity development and well-being, but likely in the opposite direction (e.g., external locus of control, diffusion, and comfort with ambiguity). In any case, the emphasis of some participants on experiential as opposed to ideational conceptualizations of God contradicts current trends in psychological research and opens up possibilities for future inquiry that take a more experiential approach.

Association between perceptions of God and perceptions of spirituality. When participants' descriptions of spirituality were compared with their descriptions of God, it was clear that they had an easier time describing God than they did describing spirituality. This finding may imply a more abstract nature of spirituality in general than to the embodiment of spirituality in a Divine Being. This finding also seems indicative of religious influences regarding beliefs about God popularized in stories, sermons, and scriptural texts. Conversely, the more abstract one's view of God, the 
less personalized were the descriptions of spirituality. Again, given the relational nature of spirituality as described by this sample of participants, it seems logical that if one is not able to clearly describe God where more concrete information is available, then spirituality would be less concretized.

Themes apparent in the analyses that were surprising included Participants’ perceptions of spirituality and perceptions of God were consistent within an integrated belief system; perceptions of spirituality were uniquely different whe.n God is not viewed in anthropomorphic terms or is not viewed as relevant; participants viewed religion as the culprit for most negative perceptions rather than spirituality or God; superficial exploration of beliefs in God and perceptions of spirituality were often deemed sufficient.

The worldviews of the participants were integrated in their core belief systems, such that for theistic participants, descriptions of spirituality and descriptions of God followed religious beliefs. This meant that God was entirely relevant and integrated within participants’ descriptions, or mention of God was completely absent in favor of scientific, agnostic/atheistic beliefs. Whether or not participants mentioned God, beliefs about spirituality were consistently described as being a moral compass, a source of meaning and direction, and highly personal.

Whenever individuals said anything critical or demeaning in response to the questions about spirituality or God, the content almost always pointed to religion as an institution (e.g., bad experiences with "church”). This finding parallels the theme that participants did not deeply question their own spiritual beliefs and therefore emphasized problems in the belief systems of others, which phenomenon is indirectly 
related to the fundamental attribution error (one's own errors are due to the situation, while the errors of others are a result of their disposition). The next section will compare the findings of this study with classical theories in psychology and then address how they relate to contemporary psychology. Comparisons of Themes with Psychological Theorists' Ideas

Comparisons with classical theorists. Classical theoretical models that attempted to define spirituality match only superficially with the findings of this study. An example of one such superficial similarity is that many participants described a dependence upon God as a Father, which coincides with Freud's assertion of infantile yearnings for a relationship with their father (but no participants overtly associated God as a substitute for their genetic father). However, Freud's idea of spirituality being a "mystical sense of oneness with the universe" was not consistent with the results, nor was the association of religious beliefs serving the purpose of suppressing sexuality or aggression. The conflict that Freud's theory espoused between religion and psychology does not match the participants' descriptions in the interviews in this study.

Jung's emphasis on one's connection to God and coming to know Him through personal experience is consistent with many of the descriptions of spirituality in this study. However, in some cases participants described their beliefs in terms of rationality and faith, ideas not explicit within Jung's theory. Nevertheless, Jung's ideas surrounding archetypes were clearly evident in some of the descriptions of God.

Fromm's belief that God could not be known and that experience had to be tied to God was not consistent with participants' perceptions in most cases. Participants 
described spirituality in terms of communing with God and having a personal relationship with Deity, although there was a perceived gap between them and God. There were also a handful of participants who described personally meaningful spirituality without any mention of God.

William James’ theory was generally consistent with responses in this study, particularly the emphasis on God as a provider of saving experiences. Many participants spoke in terms of God helping them or saving them in times of crises. Furthermore, James’ belief that religious experience was a connection with whatever one happens to consider to be divine was clearly articulated at many levels in the descriptions by nearly all participants. Participants who described God more in terms of their own experience were more equipped to share concrete ideas about Deity. This would support James’ idea of religious experience being foundational to one’s worldview. Not as well supported in the responses were James’ ideas regarding the separation of the institution and the individual; nevertheless, individuals having anything at all critical to say exclusively directed it at institutional religion.

Gordon Allport’s ideas around intrinsic/extrinsic orientations to spirituality were evident within the participants' descriptions. However, his view that people tend to turn away from a particular religion and look elsewhere for spirituality received mixed support. Some participants clearly have attempted a separation with religion in favor of a more free spirituality, but their religious beliefs, or those of others, still heavily influenced their ideas about spirituality. Dissention from religion seems to be more as Allport believed, from a particular religion, not from religion itself. Cases 
where participants with perceived Eastern, atheistic/agnostic, and scientific views generally supported Allports’ ideas.

Maslow’s dichotomy of religion as institution and religion as individual, with the former being a hindrance to self-actualization, warrants some attention from the findings in this study. While clearly religion is integrated into individuals’ perceptions of spirituality and God, there is some evidence that religious orthodoxy and hang-ups with religion may act as a barrier to experiencing spirituality and God more deeply than otherwise might be the case. Participants' descriptions of extraordinary spiritual experiences that help one rise to a higher level appear to support Maslow's idea of “peak experiences.” Maslow’s belief that religion and spirituality is about meaning being tied to what transcends the self was supported in many of the participants' descriptions. His view that the majority of this process is unconscious may be supported; participants described ideas that were the "background" to the lives, with infrequent and usually superficial exploration/challenge of spiritual beliefs.

Although it is important to contrast the results of the present study with the ideas of early theorists in psychology, it is perhaps even more important to contrast the results of the present study with contemporary theorists. Such comparisons are more contextually relevant and may generate implications for future work in research and counseling.

Comparisons with contemporary theorists. Themes in the present study relating to spirituality and God image support as well as contradict aspects of contemporary research in psychology. The finding that participants had difficulty in defining spirituality runs counter to Zinnbauer and Pargament (2002) who maintained that 
individuals were clear in their thinking and able to describe spirituality and religion as well as being able to differentiate the two. In this study, many of the participants' did not describe spirituality in a clear, well-articulated fashion but rather in vague, abstract, and non-specific terms. Likewise, the finding that religious beliefs are embedded in descriptions of spirituality and perceptions of God clearly indicates that individuals in this study had difficulty parsing out differences among the two constructs. However, the findings are consistent with the general body of psychological research that identifies spirituality as being a multi-dimensional construct. This is where the agreement ends and the debate within the field of psychology begins.

The consistent problem pointed out by researchers is the saturation of vague definitions of spirituality with a complete lack of consensus (Spilka et al., 2003; Zinnbauer \& Pargament, 2005). Present findings point to some possible explanations as to the difficulty psychology faces in defining spirituality. It may well be that the spirituality can only be described and not defined because an individual's language and vocabulary may not be adequate in capturing the highly subjective nature of spirituality and the often attending mystery surrounding it. Another possible explanation could be the increased multi-cultural and ecumenical nature of our society that was not as prevalent in the day of many of the classical theorists. For example, a contemporary criticism of Freud concerns his sexist views of intra-psychic events. Similar ideas presented today would fall under more scrutiny by researchers.

Contemporary theorists' definitions of spirituality capture, at least in part, several aspects of the perceptions of participants in the present study. A possible 
reason for this may be the more multi-dimensional conceptualization and measurement of spirituality today compared to more uni-dimensional conceptualizations/measures of the past. Another possible explanation for greater alignment with contemporary theories could be related to historic/cultural overlaps; contemporary theorists live in the same time and cultural space as the participants in this study, so any similarities in language may stem from such shared contexts.

Findings in the present study highly overlap contemporary theorists' views about spirituality and God image. The elements of contemporary definitions of spirituality that are consistent with participants' descriptions of spirituality and God in this study are reviewed in the following paragraphs.

Humanistic/Existential. In the present study, participants repeatedly alluded to the role that spirituality plays in their own life. They often discussed such critical issues as meaning making, direction, and purpose in life. Indeed, spirituality was seen as foundational to their interpretation of life events. Hence, the mention of spirituality being an existential part of life is warranted at a fundamental level.

Introspective. Individual responses to the questions about spirituality and the nature of God demonstrated that they are highly subjective, internal, and sacred beliefs. Even in the cases where God played no role, spirituality was often described as an internal barometer for making decisions and weighing moral implications. Contemporary definitions are consistent with this study, but definitions that only included this aspect would be limited.

Multidimensional. As stated earlier, and corroborated with the current body of literature, spirituality and perceptions of God are inherently multidimensional 
concepts. This finding was blatantly evident when comparing participant responses. Individuals mentioned many components of beliefs, actions, values, relationships, emotions, etc. Spirituality and perceptions of God comprise many issues at many levels. However, they not only consist of many components, but they also seem to be integrated within the participants' entire worldview, such that reference to spirituality and God image without understanding the broader worldview of the individual would not adequately represent what those concepts entail for the person.

Transcendent. Participants generally reported that spirituality consists of extraordinary experiences, not typically part of their day-to-day lives. Spirituality was described in terms of heightened feelings, overcoming impossible adversity, and emotions connoting intimacy with Deity or with the Sacred. While spirituality encompasses these aspects it would still be limiting to describe spirituality only in these terms.

Connectedness/Relational. An emergent theme and one interwoven throughout several of the other themes in this study is the importance placed in relationships. These relationships involve Deity, others, and nature. In some instances the relational aspects of spirituality were the only dimension reported. Theorists have increasingly argued for descriptions of spirituality with individual's perceptions of God was the idea that definitions of spirituality must exist within a relational context (Hall \& Brokaw, 1995; Hill \& Hall, 2002; Paloutzian \& Park, 2005; Spilka et.al, 2003). Given the highly relational and integrated nature of spirituality to God, it would appear that definitions of spirituality would indeed benefit by including relational components. These findings also demonstrate the relevance of work based 
on attachment theory such as the salience of individuals' attachment to God (Kirkpatrick, 2005; Rowatt \& Kirkpatrick, 2002). Kirkpatrick’s work built upon Ainsworth's three attachment styles (secure, avoidant, and anxious-ambivalent) that were all demonstrated by different participants within this study. Many participant responses reflected a sense of security and faith in God when He was perceived as able and willing to assist in times of crises. Their belief that God would intervene in their behalf in times of trouble was represented in more upbeat and positive perceptions about spirituality and the nature of God. A handful of participants felt that God was "out there" and not at all interested in their life. Their report did not state that God disliked them, rather that Deity was in a distant part of the universe, preoccupied with greater things, and not interested in their condition. This led to more individualistic perceptions of spirituality and a less important role in their lives. Anxious/ambivalent type of attachment was also prevalent within the perceptions of God in this study. The theme of a perceived gap between them and God creating dissonance is consistent with this idea. Although the participants viewed God in benevolent terms, there were the inconsistencies and troubled anxiety of expectancy about God and his willingness or ability to help them in times of trouble. These dissonant feelings brought about the desire to be more worthy of God's love and therefore his help through reaching greater personal perfection and performing more works.

In sum, there was a great degree of overlap between the perceptions of spirituality and God expressed by the participants in this study and the ideas promoted in several contemporary psychological theories. However, the descriptions provided by participants were much more rich and varied than contemporary theories indicate. 
They generally fail to capture both the internal consistency within participants' beliefs and the complexity across participants' beliefs. The findings from this study clearly show the benefits of using a qualitative method to describe spirituality and God image from the perspective of the individual. There is much to be gleaned from allowing people to describe their worldview in relation to topics relevant to psychology. Implications

There are several implications of this study for the fields of psychology and counseling. First, worldviews that include God and religion are integrated into descriptions of spirituality and therefore should not be minimized within the professional literature. Second, multi-dimensional approaches/theories/interventions are preferable to traditional, uni-dimensional approaches. Third, individuals’ perceptions of spirituality and perceptions of God involve relationships, which fact facilitates the integration of such issues into counseling. Fourth, individuals’ perceived dissonance with God may be useful in the treatment of such issues as perfectionism, social anxiety, and identity development. Finally, several promising directions for future research are highlighted.

Worldviews that include God and religion are integrated into descriptions of spirituality and therefore should not be minimized within the professional literature. A troubling trend mentioned throughout this study is psychology's efforts to remove the mention of Deity from definitions of spirituality (Hill \& Hall, 2002). To do so runs counter to the evidence presented in this study. Participants' religious beliefs and view of God's role/characteristics are tied to their definitions of spirituality. Counselors therefore could benefit from openness to religious worldviews of their 
clients. Counselors working with religious clients may want to consider theistic strategies for their practice (see Richards \& Bergin, 2005). Furthermore, interventions aimed at helping clients enhance their worship experience (e.g., talking about spiritual experiences, asking questions that promote religious dialogue, discussing service opportunities, illuminating the relational components of worship, etc.) could help clients to more effectively use religion to build their spirituality.

One size does not fit all when it comes to defining spirituality and God. Descriptions of spirituality and Deity are quite varied. It stands to reason that a multidimensional, holistic approach may be warranted to address such plurality. Indeed, reductionistic, one-size-fits-all definitions would be problematic with such diverse religious and spiritual worldviews. Given the deeply rooted nature of individuals’ beliefs about God and spirituality, narrow definitions would fail to account for the complexity and depth of these beliefs. Instead, efforts in research and counseling practice might yield more fruitful results by ascertaining individuals’ worldviews rather than restricting focus to universal definitions of restricted dimensions. Furthermore, in clinical settings, just because client may have trouble verbalizing spiritual issues does not mean that spiritual experiences do not take place or are irrelevant to counseling. Another clinical implication is that therapists and clients will have divergent worldviews regarding spirituality, even if they ostensibly adhere to the same religious beliefs, and therapists should therefore be wary of generalizing their own experiences/beliefs to the client. An additional implication for counseling is that assessment is paramount when seeking to understand the client's worldview revolving around spirituality and God. Some clients may have no interest in spirituality, while 
others may view it as integral to their day-to-day lives. A mismatch in approach would likely be ineffective if not damaging to the therapeutic alliance. Furthermore, clients who view God as a source of help may find therapy a useful place to explore how God could promote healing in their lives.

Individuals' perceptions of spirituality and perceptions of God involve relationships, the foundational component of counseling. Perceptions of spirituality and perceptions of God were often relational in nature. This finding coincides with the affirmation that the two should not be parsed out but rather included together (Hall \& Brokaw 1995; Hill \& Hall, 2002). Attachment theory and other relevant work have previously highlighted the critical association between relationships with others and with God (Mitchell, 2000). Since counseling is highly relational in nature and involves helping others construct more meaningful relationships, clients’ relationships with the Divine can be integrated effectively into counseling.

The perceived dissonance with God has implications for issues of identity development, perfectionism, etc. The theme illustrating the perceived gap between a person and God along with the corresponding dissonance warrants further investigation. Particularly, it may be that such a worldview might be related to clinical issues such as perfectionism, social anxiety, and identity development. Further work could be done to explore this possible relationship. Similar work could also be done with the similar variables of religious orthodoxy/dogmatism. Also, questions can be raised about what a worldview of having to "do" rather than "be" means to a client psychologically. 
In counseling the religious/spiritual client, it may be appropriate to gather beliefs and views of Deity in an effort to be more useful in understanding the client and some latent anxiety about God, spirituality, and religion. In addition, since personal experiences among participants were related to richer descriptions of God in this study, part of the work in counseling could be to support and encourage clients to seek out experiences with the Divine.

\section{Limitations of the Present Study}

The present study had many limitations. Of course, qualitative findings such as those reported here cannot be assumed to generalize to other populations. This particular study involved participants with a high composition of Christian religious affiliation who were selected from a restricted geographical area noted for religious participation relative to coastal and urban areas of the United States. Even though a variety of Christian denominations were inferred to be represented from their responses (Catholic, Protestant, Latter-day Saint, etc.), the findings of this study should not be transposed into any other context. Second, a clear limitation of the present study was that some of the participants were not native English speakers, which likely contributed to some of the vagueness and lack of specificity described in this study. Third, the questions about spirituality and the questions about God were asked in the same interview. Although these questions were separated by three intermediate questions, there could have been spillover in content across participants' descriptions, which likely contributed to some of the continuity in beliefs that was highlighted. Fourth, the fact that the data was archival, and the fact that the interviews were not conducted with this particular analysis in mind, was a limitation and may 
have contributed to a loss of some perspective and clarification of meaning. Lastly, I note my own limitations and biases as a coder and interpreter. While the many steps outlined in the methods section were in place to deter this as best as possible, I recognize that my own experiences continue to influence the interpretations proffered in this study.

\section{Directions for Further Research}

These findings suggest many fruitful areas for future research. One area of research clearly evident would be to replicate this study with a population more inclusive of individuals with Eastern, atheistic/agnostic, and scientific views about God and the nature of spirituality. In particular, the emphasis on "action” and "doing” among Christians contrast completely with the perspective of "being” and “essences” characteristic of Eastern and agnostic perspectives. Related to this area of research, it seems that investigation into extraordinary spiritual experiences themselves would be

fruitful. Some work has been done in this area already in the subfield of transpersonal psychology; however, due to lack of rigorous research methods and controversial findings, that work has not been influential. If research investigating "peak experiences” and other transcendent spiritual events could be conducted in ways more congruent with professional expectations, it may receive more attention in the literature.

In quantitative studies, measures will likely need to be multidimensional to adequately study the construct of spirituality. Furthermore, because the construct of spirituality may be more abstract than the concept of Deity, one possibility in the area of measurement would be to develop measures that are more based on perceptions of 
God than upon perceptions of spirituality in general. Such grounding of the concepts may enhance the reliability of the measures and improve their ability to accurately evaluate the individuals’ worldviews regarding spiritual topics.

Future research could also explore individual's negative experiences with religion to specify common themes that may be fueling the religion/spirituality debate. Understanding the nature of individuals’ dissonance with spirituality and God, especially in relation to an anxious/ambivalent view of Deity, could also result in clinical insights.

Participants' descriptions of spirituality in the present study seemed to indicate that their beliefs are typically formed in childhood but then change slightly at some point and then remain relatively stable thereafter. Psychological research has rarely examined how spiritual beliefs change over time. Previous research has not highlighted the foundations for individuals' spiritual beliefs. Why do individuals hold the beliefs they do? Given the purported importance of individuals' beliefs about spirituality and God, why are those beliefs maintained relatively consistently over time when predominantly superficial exploration or acceptance of common practice suffices? Contradictions such as these seem fertile ground for inquiry.

Research could also study the implications of talking about clients religious beliefs to assist them in better defining and experiencing their spirituality. In other words, finding out the most effective ways of helping a client explore their beliefs, engage in service, or promote dialogue on the subject.

As with most psychological research, the current study was limited to the perceptions of individual participants. Contextual and group factors were not 
considered. Hence, future research could be done to examine the role of family, culture, and social groups (e.g., government) on beliefs and any associated themes, positive or negative.

\section{Conclusion}

Many individuals ascribe great importance to religion and spirituality, which are complex belief systems relevant to many psychological variables. The present study yielded insights into the nature of why spirituality is difficult to define, provided a rationale for integrating religion and Deity in descriptions of spirituality, and revealed the integrated nature of relational attributes in describing both constructs. By contrasting the findings of the present study with both classical and contemporary theories this study helped to show where psychological models do and do not coincide with individuals’ lived experience. The qualitative method used in this study was useful in understanding the nature of spirituality and God from the point of view of the participants, something rarely considered in extant studies on the topic. The themes noted in the present study may be useful in generating additional questions and constructing future research to further the inquiry reported here. 


\section{References}

Ainsworth, M., Blehar, M., Waters E., \& Wall., S. (1978). Patterns of attachment: A psychological study of the strange situation. Hillside, NJ: Earlbaum.

Allport, G. (1952). The individual and his religion. New York: The Macmillan Company.

Armstrong, T. D. (1995, August). Exploring spirituality: The development of the Armstrong Measure of Spirituality. Paper presented at the annual convention of the American Psychological Association, New York, NY.

Bauman, Z. (1998). Postmodern religion? In P. Heelas (Ed.), Religion, modernity and postmodernity (pp. 55-78). Oxford, England: Blackwell.

Benner, D. G. (1989). Toward a psychology of spirituality: Implications for personality and psychotherapy. Journal of Psychology and Christianity, 5, 1930.

Benson, P., \& Spilka, B. (1973). God image as a function of self-esteem and locus of control. Journal for the Scientific Study of Religion, 12(3), 297-310.

Bergin, A. E. (1980). Psychotherapy and religious values. Journal of Consulting and Clinical Psychology, 48(1), 95-105.

Bowlby, J. (1969). Attachment. Vol. 1 of Attachment and loss. New York: Basic books.

Bowlby, J. (1973). Separation, anxiety, and anger. Vol. 2 of Attachment and loss. New York: Basic books. 
Brokaw, B. F., \& Edwards, K. J. (1994). The relationship of God image to level of object relations development. Journal of Psychology and Theology, 22(4), 352371.

Bruner, J. (1986). Actual minds, possible worlds. Cambridge, MA: Harvard University Press.

Clark, W. H. (1958). How do social scientists define religion? Journal of Social Psychology, 47, 143-147.

CNN-Gallup. (2005). How Americans view their own spirituality and religious faith.

Retrieved August 1, 2007, 2007, from

http://www.religioustolerance.org/chr_poll7.htm\#spir

Dollahite, D. C. (1998). Fathering, faith, and spirituality. Journal of Men’s Studies, 7, 3-13.

Doyle, D. (1992). Have we looked beyond the physical and psychosocial. Journal of Pain and Symptom Management, 7, 3-13.

Elkins, D. N., Hedstrom, L. J., Hughes, L. L., Leaf, J. A., \& Saunders, C. (1988). Toward a humanistic phenomenological spirituality: Definition, description, and measurement. Journal of Humanistic Psychology, 28(4), 5-18.

Ellis, A. (1980). Psychotherapy and atheistic values: A response to A. E. Bergin’s “Psychotherapy and Religious Values.” Journal of Consulting and Clinical Psychology, 48, 635-639.

Emmons, R. A. (2003). The Psychology of Religion. The Annual Review of Psychology, 54, 337-402. 
Emmons, R. A., \& Paloutzian, R. F. (2003). The psychology of religion. Annual Review of Psychology, 54, 377-402.

Eurelings-Bontekoe, E. H., Hekman-Van Steeg, J., \& Verschuur, M. J. (2002). The association between personality, attachment, psychological distress, church denomination and the God concept among a non-clinical sample. Mental Health, Religion \& Culture, 8(2), 141-154.

Fahlberg, L. L., Fahlberg, L. A. (1991). Exploring spirituality and consciousness with an expanded science: Beyond the ego with empiricism, phenomenology, and contemplation. American Journal of Health Promotion, 5, 273-281.

Frankl, V. E. (1975). The unconscious God: Psychotherapy and theology. New York: Simon and Schuster.

Fontana, D. (2003). Psychology, religion, and spirituality. Malden, MA: BPS Blackwell.

Forsyth, J. (2003). Psychological theories of religion. Upper Saddle River, NJ: Prentice Hall.

Freud, S. (1907). Obsessive Acts and Religious Practices (J. Riviere, Trans.). In E. Jones (Ed.), Sigmund Freud Collected Papers (pp. 25-35). New York: Basic Books.

Freud, S. (1961). The future of an illusion. New York: W.W. Norton.

Fromm, E. (1951). Psychoanalysis and religion. New Haven, CT: Yale University Press.

Gallup. (2006). Retrieved July 18, 2006, from http://brain.gallup.com/content/default.aspx?ci=1690\&pg=2. 
Gibbs, G. R. (2002). Qualitative data analysis: Explorations with NVivo. Philadelphia: University Press.

Gorsuch, R. L. (1984). The boon and bane of investigating religion. American Psychologist, 39(3), 228-236.

Gorsuch, R. L. (2002). Integrating psychology and spirituality. Westport, CT: Praeger.

Hall, T. W., \& Brokaw, B. F. (1995). The relationship of spiritual maturity to level of object relations and God image, Pastoral Psychology, 43(6) 373-391.

Hart, T. (1994). The hidden spring: The spiritual dimension of therapy. New York: Paulist Press.

Hill, P. C. (1999). Giving religion away: What the study of religion offers psychology. The International Journal for the Psychology of Religion, 9(4), 229-249.

Hill, P. C. (2005). Measurement in the psychology of religion and spirituality: Current status and evaluation. In R. F. Paloutzian \& C. L. Park (Eds.), Handbook of the psychology of religion and spirituality (pp. 43-61). New York: The Guilford Press.

Hill, P. C., \& Hall T. W. (2002). Relational schemas in processing one’s image of God and self. Journal Psychology and Christianity, 21(4), 365-373.

Hill, P. C., \& Hood, R. W. (1999). Measures of religiosity. Birmingham, AL: Religious Education Press.

Hill, P. C., \& Pargament, K. I. (2003). Advances in the conceptualization and measurement of religion and spirituality. American Psychologist, 58(1), 64-74.

Hill, P. C., Pargament, K. I., Hood, R. W., McCullough, M. E., Sewyers, J. P., Larson, D. B., et al. (2000). Conceptualizing religion and spirituality: Points of 
commonality, points of departure. Journal for the Theory of Social Behaviour, 30(1), 51-77.

Jackson, A., \& Patton, M. (1992). A Hermeneutic approach to the study of values in counseling. Counseling \& Values, 36(3), 201-209.

James, W. (1902/1963). Varieties of religious experience. New Hyde, NY: University Books.

James, W. (1907/1974). Pragmatism and four essays from the Meaning of Truth. New York: New American Library.

Jung C. G. (1938). Psychology and Religion. New Haven, CT: Yale University Press.

Jung, C. G. (1971). Instinct and the unconscious. In the portable Jung. New York: Viking Press.

Kirkpatrick, L. A. (1995). Attachment theory and religious experience. In R. W. Hood, Jr. (ed.), Handbook of religious experience (pp. 446-475). Birmingham, AL: Religious Education Press.

Kirkpatrick, L. A. (2005). Attachment, evolution, and the psychology of religion. New York: Guilford.

Kirkpatrick, L. A., \& Shaver, P. R. (1990). Attachment theory and religion: Childhood attachments, religious beliefs, and conversion. Journal for the Scientific Study of Religion, 29, 315-334.

Kirkpatrick, L. A., \& Shaver, P. R. (1992). An Attachment-Theory approach to the psychology of religion. The International Journal for the Psychology of Religion, 2(1), 3-28. 
Koenig, H. G., McCullough, M. E., \& Larson, D. B. (2001). Handbook of religion and mental health. New York: Oxford University Press.

Kunkel, M. A., Cook, S., Meshel, D. S., Daughtry, D., \& Hauenstein, A. (1999). God images: A concept map. Journal for the Scientific Study of Religion, 38(2), 193202.

Kvale, S. (1996). Interviews: an introduction to qualitative research interviewing. Thousand Oaks, CA: Sage Publications.

Lakoff, G. (1980). Metaphors we live by. Chicago: University of Chicago Press.

Maslow, A. H. (1970). Religion, values, and peak-Experiences. New York: Viking Press.

Miller, W. R., \& Thoresen, C. E. (2003). Spirituality, reigion, and health. American Psychologist, 58(1), 24-35.

Mitchell, S. A. (2000). Object relations theory. In Kazdin, A. E., (Ed.), Encyclopedia of Psychology (pp. 488-490). Washington, DC: American Psychological Association.

O’Brien, M. E. (1982). Religious faith and adjustment to long term hemodialysis. Journal of Religion and Health, 21, 68-80.

Palmer, S. J. (1997). Religions of the world: a Latter-day Saint view ([2nd general ed.). Provo, Utah: Brigham Young University.

Paloutzian, R. F., \& Park, C. L. (2005). Integrative themes in the current science of the psychology of religion. In R. F. Paloutzian \& C. L. Park (Eds.), Handbook of the psychology of religion and spirituality (pp. 3-20). New York: Guilford. 
Powell, L. H., Shahabi, L., \& Thoresen, C. E. (2003). Religion and spirituality. American Psychologist, 58(1), 36-52.

Richards, P. S., \& Bergin, A. E. (1997). A spiritual strategy for counseling and psychotherapy (1st ed.). Washington, DC: American Psychological Association.

Richards, P. S., \& Bergin, A. E. (2005). A spiritual strategy for counseling and psychotherapy. ( ${ }^{\text {nd }}$ ed.). Washington, DC: American Psychological Association.

Rowatt, W. C., \& Kirkpatrick, L. A. (2002). Two dimensions of attachment to God and their relation to affect, religiosity, and personality constructs. Journal for the Scientific Study of Religion, 41(4), 637-651.

Schaap-Jonker, H., Eurelings-Bontekoe, E., Verhagen, P. J., \& Zock, H. (2002). Image of God and personality pathology: An exploratory study among psychiatric patients. Mental Health, Religion \& Culture, 5(1), 55-71.

Scwandt, T. A. (2000). Three epistemological stances for qualitative inquiry. In N. K. Denzin \& Y. S. Lincoln (Eds.), Handbook of qualitative research, $2^{\text {nd }}$ ed. (pp. 189-213). Thousand Oaks, CA: Sage.

Shafranske, E. P., Gorsuch, R. L. (1984). Factors associated with the perception of spirituality in psychotherapy. Journal of Transpersonal Psychology, 16, 231-241.

Shafranske, E. P., Sperry, L. (2005). Addressing the spiritual dimension in psychotherapy: Introduction and overview. In E. P. Shafranske \& L. Sperry (Eds.), Spiritually oriented psychotherapy (pp. 11-29). Washington, DC: American Psychological Association.

Spilka, B., Hood, R. J., Hunsberger, B., \& Gorsuch, R. (2003). The psychology of religion (3rd ed.). New York: Guilford. 
Tart, C. (1975). Introduction. In C. T. Tart (Ed.), Transpersonal psychologies (pp. 37). New York: Harper \& Row.

Vaunn, F. (1991). Spiritual issues in psychotherapy. Journal of Transpersonal Psychology, 23, 105-119.

Zinnbauer, B.J., \& Pargament, K. I. (2005). Religiousness and Spirituality. In R. F. Paloutzian \& C. L Park (Eds.), Handbook of the Psychology of Religion and Spirituality (pp. 21-42). New York: Guilford.

Zinnbauer, B. J., Pargament, K. I., \& Scott, A. B. (1999). The emerging meanings of religiousness and spirituality: Problems and prospects. Journal of Personality, 67(6), 889-919.

Zinnbauer, B. J., Pargament, K. I., Cole, B., Rye, M. S., Butter, E. M., Belavich, T. G., et al. (1997). Religion and spirituality: Unfuzzying the fuzzy. Journal for the Scientific Study of Religion, 36(4), 549-564. 


\section{Appendix A \\ Empirical Measures of God Image}

Adjective Ratings of God. This instrument was designed to get past vague concepts of God to those more specific. The survey provides a three number system of "1" does not describe God, "2" describes God, and "3" describes God well. The participant then puts the number by each of the 91 descriptive words that describe God.

Concepts of God and Parental Images. This scale stems from the psychoanalytic tradition and looks at the relationship between God and ones parents. The scale consists of 36 items equally split between maternal and paternal qualities. The items are rated by the participant on a Likert scale to look at the degree the quality resembles the target image. The scale is of practical use because of its ease in administration and scoring.

God Image Inventory (GII). The GII measures six different aspects of God image using 156 items to examine: Influence, Providence, Presence, Challenge, Acceptance, and Benevolence. The instruments aim is to “...assess individuals' felt sense of who God is for them” (Hill and Hood, 1999, p. 399).

Loving and Controlling God Scales. The purposes of these scales are to measure two main aspects of God image involving a loving God image and a controlling God image. Each scale consists of five sets of adjectives that look at such adjectives as rejecting-accepting, approving-disapproving, strict-lenient, etc. The paper-and-pencil 
measure is easy to administer and has had much use in demonstrating the relationship of self-esteem to a positive God image (see Benson \& Spilka, 1973).

Nearness to God Scale. This 32-item, Christian based scale examines how respondents feel about God’s reality, nearness, and accessibility. “Individuals scoring high on this scale are characterized as feeling that they 'walk' and 'talk' with God, communicating with God regularly” (Hill and Hood, 1999, p. 408). 